Prepared in cooperation with the Geological Survey Department, Minerals Commission, and Precious Minerals Marketing Company of Ghana under the auspices of the U.S. Department of State

\title{
Alluvial Diamond Resource Potential and Production Capacity Assessment of Ghana
}

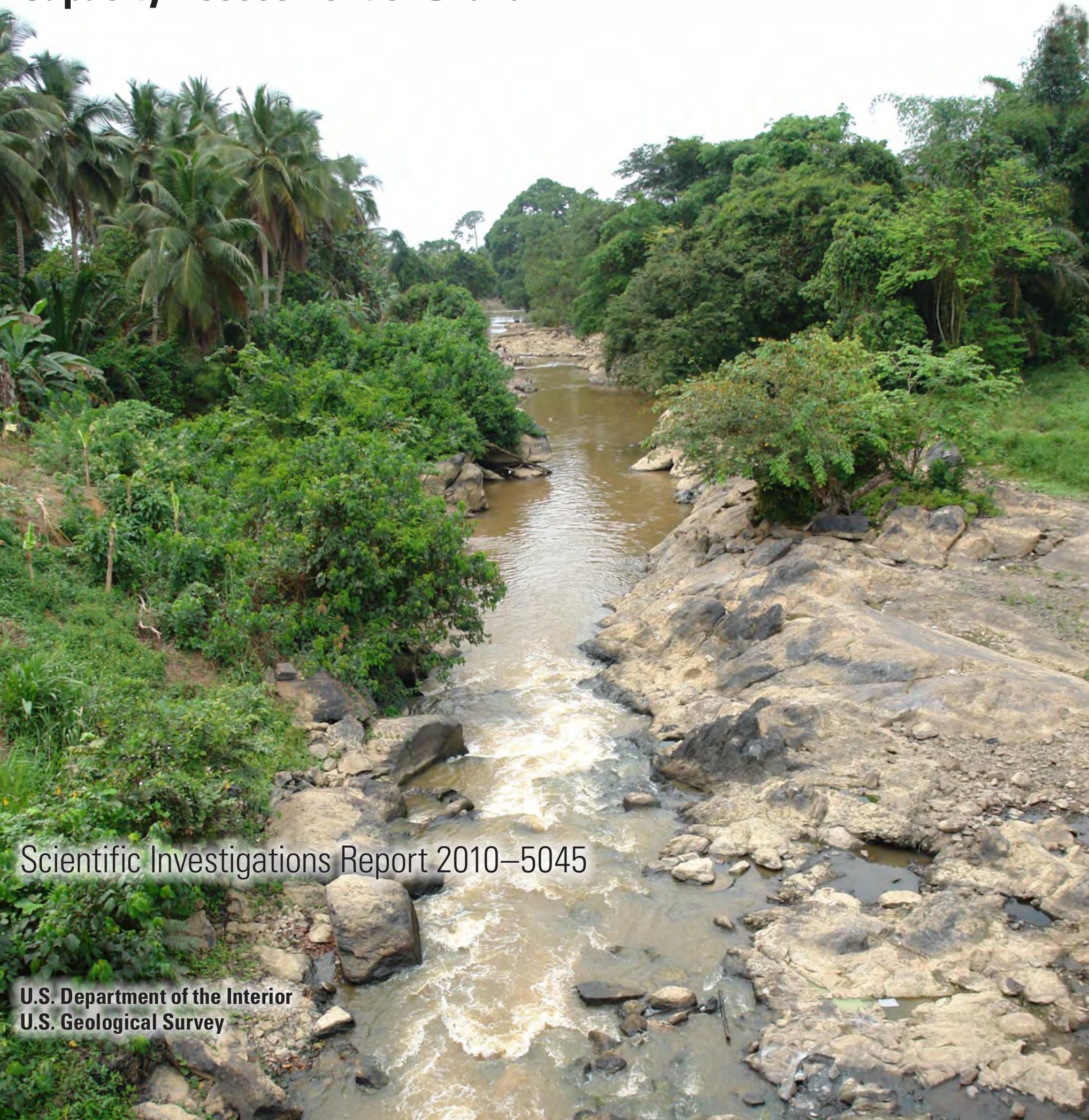


Cover. The Bonsa River flowing west-northwest from the village of Bonsa, March 2009. 


\section{Alluvial Diamond Resource Potential and Production Capacity Assessment of Ghana}

By Peter G. Chirico, Katherine C. Malpeli, Solomon Anum, and Emily C. Phillips

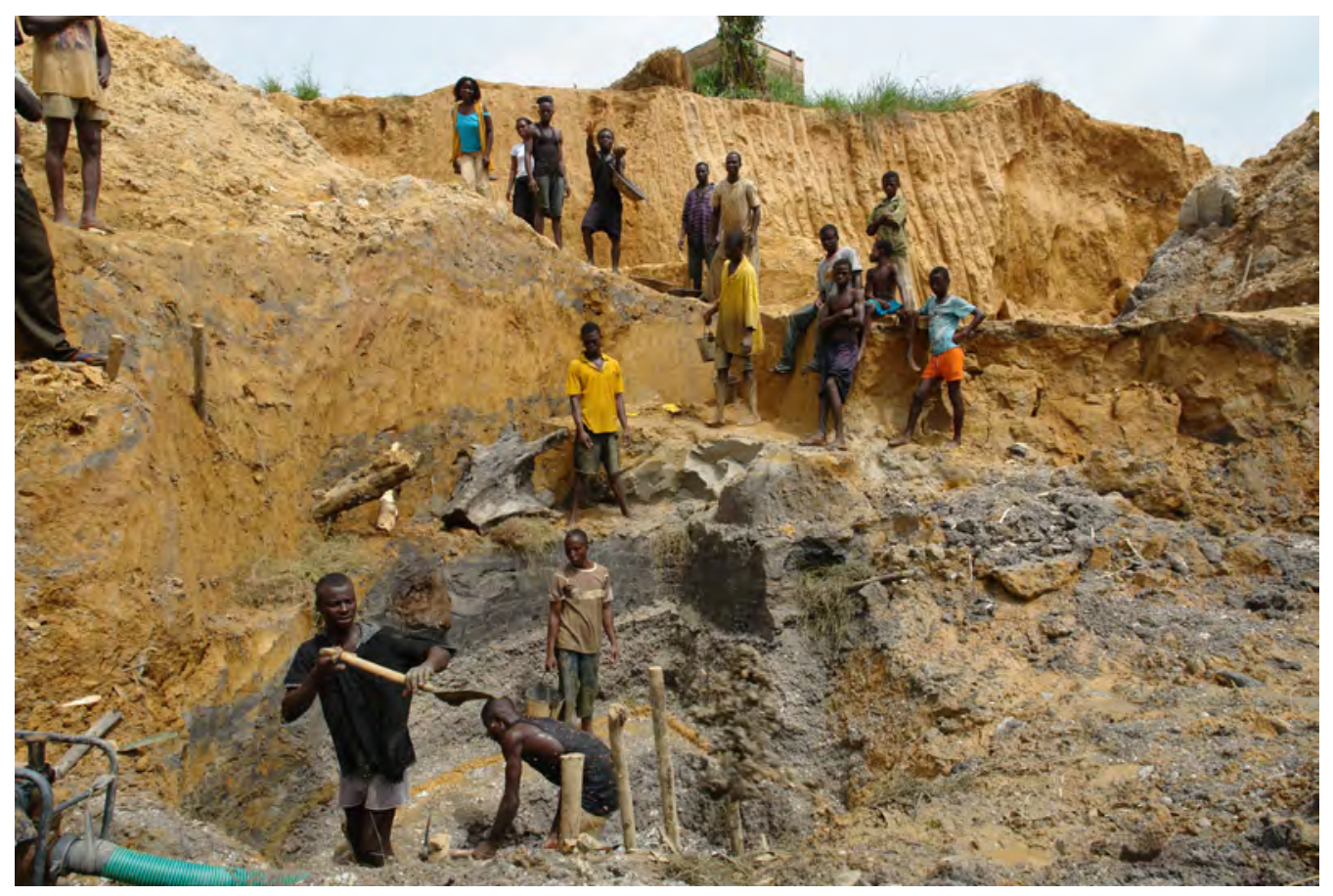

Large alluvial diamond mining site at alluvial flat in Wenchi, March 2009

Prepared in cooperation with the Geological Survey Department, Minerals Commission, and Precious Minerals Marketing Company of Ghana under the auspices of the U.S. Department of State

Scientific Investigations Report 2010-5045 


\title{
U.S. Department of the Interior \\ KEN SALAZAR, Secretary \\ U.S. Geological Survey \\ Marcia K. McNutt, Director
}

\section{U.S. Geological Survey, Reston, Virginia: 2010}

\author{
For more information on the USGS — the Federal source for science about the Earth, its natural and living resources, \\ natural hazards, and the environment, visit http://www.usgs.gov or call 1-888-ASK-USGS \\ For an overview of USGS information products, including maps, imagery, and publications, \\ visit http://www.usgs.gov/pubprod \\ To order this and other USGS information products, visit http://store.usgs.gov
}

\begin{abstract}
Any use of trade, product, or firm names is for descriptive purposes only and does not imply endorsement by the U.S. Government.

Although this report is in the public domain, permission must be secured from the individual copyright owners to reproduce any copyrighted materials contained within this report.
\end{abstract}

Suggested citation:

Chirico, P.G., Malpeli, K.C., Anum, Solomon, Phillips, E.C., 2010, Alluvial diamond resource potential and production capacity assessment of Ghana: U.S. Geological Survey Scientific Investigations Report 2010-5045, 25 p. 


\section{Contents}

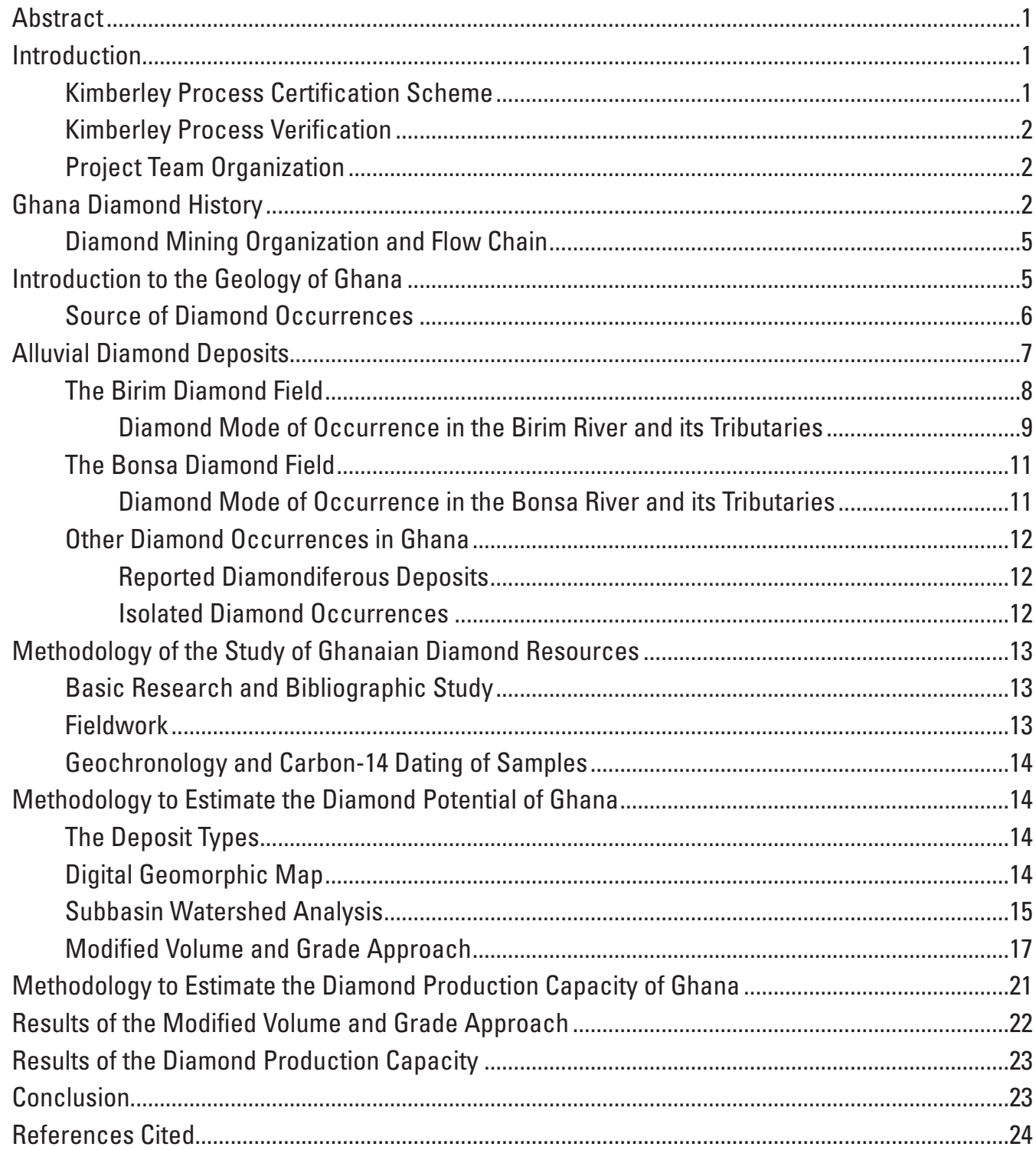




\section{Figures}

1. Graph showing Ghana Consolidated Diamonds production, volume of gravel treated, and average grade of diamondiferous gravel.....................................................

2. Map showing the geologic provinces of West Africa and diamond occurrences............6

3. Map showing the diamond mining regions and diamond occurrences in Ghana .............7

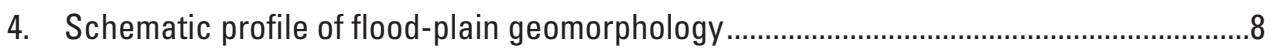

5-11. Maps showing-

5. The upper, middle, and lower sections of the Birim diamond field ...........................

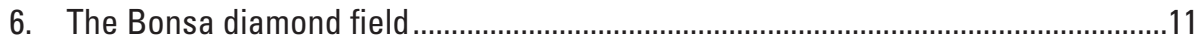

7. The surficial geomorphology of the Birim diamond field ..........................................15

8. The surficial geomorphology of the Bonsa diamond field ........................................16

9. Calculated diamondiferous subbasins of the Birim diamond field ...........................17

10. Calculated diamondiferous subbasins of the Bonsa diamond field .........................18

11. The surficial geomorphology diamond database occurrences having reliable grade information, Birim diamond field

\section{Tables}

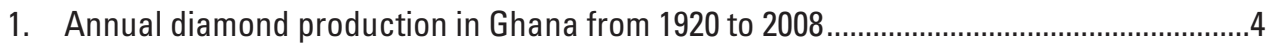

2. Upper, middle, and lower Birim diamond field reserve estimates

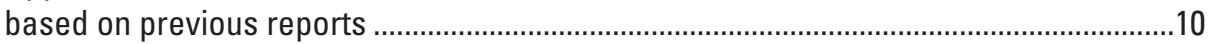

3. Average grade of Birim River diamond deposits by geomorphic type ...........................20

4. Average grade of Bonsa River diamond deposits by geomorphic type .........................21

5. Calculated diamond reserves in the Birim River diamond field.......................................22

6. Calculated diamond reserves in the Bonsa River diamond field ......................................22

\section{Conversion Factors}

\begin{tabular}{lcl}
\hline \multicolumn{1}{c}{ Multiply } & \multicolumn{1}{c}{ by } & \multicolumn{1}{c}{ To obtain } \\
\hline meter $(\mathrm{m})$ & 3.281 & foot $(\mathrm{ft})$ \\
kilometer $(\mathrm{km})$ & 0.6214 & mile $(\mathrm{mi})$ \\
square meter $\left(\mathrm{m}^{2}\right)$ & 0.0002471 & acre \\
square kilometer $\left(\mathrm{km}^{2}\right)$ & 247.1 & acre \\
cubic meter $\left(\mathrm{m}^{3}\right)$ & 35.31 & cubic foot $\left(\mathrm{ft}^{3}\right)$ \\
\hline
\end{tabular}




\title{
Alluvial Diamond Resource Potential and Production Capacity Assessment of Ghana
}

\author{
By Peter G. Chirico, ${ }^{1}$ Katherine C. Malpeli, ${ }^{1}$ Solomon Anum, ${ }^{2}$ and Emily C. Phillips ${ }^{1}$
}

\section{Abstract}

In May of 2000, a meeting was convened in Kimberley, South Africa, and attended by representatives of the diamond industry and leaders of African governments to develop a certification process intended to assure that rough, exported diamonds were free of conflictual concerns. This meeting was supported later in 2000 by the United Nations in a resolution adopted by the General Assembly. By 2002, the Kimberley Process Certification Scheme (KPCS) was ratified and signed by both diamond-producing and diamond-importing countries. Over 70 countries were included as members at the end of 2007.

To prevent trade in "conflict" diamonds while protecting legitimate trade, the KPCS requires that each country set up an internal system of controls to prevent conflict diamonds from entering any imported or exported shipments of rough diamonds. Every diamond or diamond shipment must be accompanied by a Kimberley Process (KP) certificate and be contained in tamper-proof packaging.

The objective of this study was to assess the alluvial diamond resource endowment and current production capacity of the alluvial diamond-mining sector in Ghana. A modified volume and grade methodology was used to estimate the remaining diamond reserves within the Birim and Bonsa diamond fields. The production capacity of the sector was estimated using a formulaic expression of the number of workers reported in the sector, their productivity, and the average grade of deposits mined. This study estimates that there are approximately 91,600,000 carats of alluvial diamonds remaining in both the Birim and Bonsa diamond fields: 89,000,000 carats in the Birim and 2,600,000 carats in the Bonsa.

Production capacity is calculated to be 765,000 carats per year, based on the formula used and available data on the number of workers and worker productivity. Annual production is highly dependent on the international diamond market and prices, the numbers of seasonal workers actively mining in the sector, and environmental conditions, which influence seasonal farming.

\footnotetext{
${ }^{1}$ U.S. Geological Survey, Reston, Virginia.

${ }^{2}$ Geological Survey Department of Ghana.
}

\section{Introduction}

\section{Kimberley Process Certification Scheme}

During the late 1990s the issue of "conflict diamonds," or "blood diamonds," became increasingly apparent to the global community, largely because of the civil unrest and wars in Sierra Leone and Angola. In 2001, the United Nations imposed sanctions on the Liberian diamond trade after it accused Liberian President Charles Taylor of supplying weapons and military training in exchange for diamonds from the Revolutionary United Front (RUF). The RUF was engaged in a civil war with the government of Sierra Leone. The Democratic Republic of the Congo (DRC) experienced several civil uprisings during the 1990s, and diamonds most likely funded the rebel forces.

In May of 2000, a meeting was convened in Kimberley, South Africa, by representatives of the diamond industry and leaders of African governments to develop a certification process intended to assure that rough, exported diamonds were free of conflictual concerns. Outcomes of the meeting were formally supported later in 2000 by the United Nations in a resolution adopted by the General Assembly. By 2002, the Kimberley Process Certification Scheme (KPCS) was ratified and signed by both diamond-producing and diamondimporting countries. Over 70 countries were included as members at the end of 2007.

The KPCS is an international activity whose goal is to prevent the trade of conflict diamonds while helping to protect legitimate trade through monitoring the production, exportation, and importation of rough diamonds throughout the world. To accomplish this task, the KPCS requires that every country set up an internal system of controls and checks to prevent conflict diamonds from entering an imported or exported shipment of rough diamonds. Every rough diamond and diamond shipment must be accompanied by a Kimberley Process (KP) certificate and be contained in tamper-proof packaging. The certificate includes an export origin section, an import verification section, and a security slip. The KP also requires that no diamonds are imported from or exported to a nonmember of the KPCS. Additionally, a recommendation 
of the KPCS is that all artisanal miners and buyers within a diamond producing country should be licensed by the host government (Olsson, 2006).

Countries that are members of the scheme are required to report their official amount of diamond imports and exports, as well as their value each year to the KP. These data are then made public and provided to other nongovernmental organizations in order to monitor the official statistics reported by all KP members.

\section{Kimberley Process Verification}

It is often difficult to obtain independent verification of the diamond production statistics that are provided by the countries involved in KPCS compliance issues. However, some degree of independent verification can be obtained through an understanding of a country's naturally occurring endowment of diamonds (diamond resources) and its diamond production capacity (intensity of mining activity). Studies that integrate these two components can produce a range of estimated values for a country's diamond production, and these estimates can then be compared with the production statistics released by the country. The Bureau de Recherche Géologique et Minières (BRGM) released an assessment for the Republic of the Congo (Congo Brazzaville) that developed a specific methodology for the assessment of the diamond resources as well as the production capacity (Barthélémy and others, 2006). The assessment combined both historical research and data on geologic deposits, diamond occurrences, and grades with current on-the-ground field studies and interviews with miners. The U.S. Geological Survey (USGS) and BRGM scientists began collaboration and conducted two similar studies, following the BRGM methodology. The first study was conducted for the Central African Republic (Chirico and others, 2010b), and the second study was conducted for Mali (Chirico and others 2010a). The goal of this study was to assess the geological resource potential and the rough diamond production capacity in Ghana.

The specific goals of this project are as follows:

1. Acquire and provide remote sensing imagery of alluvial diamond mining areas of the Birim and Bonsa River valleys. This imagery will assist Ghanaian government geologists in estimating artisanal alluvial production.

2. Provide training to Ghanaian counterpart agencies including the Minerals Commission and the Precious Minerals Marketing Company in the collection and reporting of mineral statistics, especially as they apply to meeting the requirements of the Kimberley Process. This support will include provision, installation, and the training of Ghanaian specialists in the use of a statistical tracking database that has been specifically designed to report rough diamond production and shipments.
3. Provide training in Geographic Information System (GIS) tools so that remote sensing can be used to monitor alluvial mining.

4. Provide a general evaluation of the number of miners active in alluvial mining, the types of grades and quality of stones that can be expected from Ghanaian alluvial deposits, and the general levels of alluvial diamond production that may be attained.

\section{Project Team Organization}

This study was conducted by a bilateral partnership of scientists and technical professionals from the USGS and the Government of Ghana.

\section{U.S. Geological Survey}

Peter G. Chirico, Project Chief, Geographer

Katherine C. Malpeli, Research Assistant

Emily C. Phillips, Research Analyst

\section{Government of Ghana}

Ministry of Lands, Forests and Mines

B.R. Yakubu, Technical Director

\section{Geological Survey Department}

John Duodu, Director

Solomon Anum, Eastern Region Director

Kwame O. Boamah, Head of the Data Management Division Issac Ashitey, Driver and Field Assistant

\section{Minerals Commission}

Ben Aryee, Chief Executive

Peter Awuah, Principal Planning and Policy Officer

Bernard Ntibrey, Senior Mining Engineer

Anthony Worlali, Mining Engineer

Precious Minerals Marketing Company, Ltd.

George Asante, Managing Director

\section{Ghana Consolidated Diamonds Ltd./ E.U. Mining Sector Support Program}

Joshua Manful, Consulting Geologist

\section{Ghana Diamond History}

Diamonds were first discovered in the Gold Coast Colony (Ghana) in 1919 near the Birim River close to the town of Abomoso (Kitson, 1919). In 1922, Junner (Archives Rehabilitation Unit (ARU), 2003a) discovered a diamond in the Bonsa 
River gravels between Mewuso and Sinteri and near Dompin. The Birim diamond discoveries led mining companies to invest along that river immediately. However, not until 1929 did organized diamond mining begin in the Bonsa River, following additional diamond discoveries made by Ghanaian prospectors in the gravels of the Chrifang and Bediebewu streams approximately 10 kilometers $(\mathrm{km})$ southwest of Tarkwa.

From 1920 through 1924, the Akim Diamond Fields Ltd. Company mined approximately 20,000 carats (kt) of diamonds in the Eastern Region along the Birim River. Several investment companies were formed during the early years of diamond mining and exploration in Ghana (then called the Gold Coast), and the exploitation of deposits began. In 1924, the Consolidated African Selection Trust (CAST) was formed and became the major diamond mining company in Ghana. Over 2 million carats were mined by CAST from 1924 to 1939 . CAST's early success led to investment in other diamond exploration and mining ventures in West Africa. In particular, they launched exploration and mining syndicates in Côte d'Ivoire, Guinea, Sierra Leone, and Liberia. The West African Diamond Syndicate (WADS), the Amalgamated Mining Company, Dunkwa Goldfields Ltd., the Holland Syndicate, and Cayco Ltd. were several other prominent diamond mining companies in Ghana.

Labor and equipment shortages during World War II affected all of the diamond mining companies throughout West Africa. Nearly a decade passed before diamond production in Ghana achieved pre-war levels. Also, diamond producers had problems with illegal miners on their concessions. Companies had to invest more time and money into security and the policing of mining sites, which ultimately contributed to declining profits.

In 1957, Ghana became the first subSaharan African country to gain independence. Under President Kwame Nkrumah, the government established the Mineral Act of 1962, which vested the ownership of minerals in the President, on behalf of the Republic and the people of Ghana, and established that the minerals be sold exclusively to a Ghanaian government agency. In 1963, the Ghana Diamond Marketing Board (later renamed the Precious Minerals Marketing Company, PMMC) was established as a statutory corporation, and all diamond producers were required to sell their diamonds to the board, which then exported them (Tsikata, 1997).

Nkrumah's government was overthrown in 1966, and several military and civilian governments followed in succession until the establishment of a stable democracy in 1992. In 1972, the National Redemption Council (NRC) instituted a policy of acquiring majority shares in mines in which the government was either a minority shareholder or held no shares at all (Tsikata, 1997). As a result, the government established Ghana Consolidated Diamonds Ltd. (GCD) to take over a majority of shares of all of CAST's diamond holdings. GCD and CAST became joint partners in diamond mining operations, as the government conducted a 55 -percent nationalization of CAST holdings, which were placed under the authority of GCD. GCD production peaked from 1974 to 1977 with average production at 2.24 million carats per year (Greenhalgh, 1985). However, in subsequent years, GCD suffered from low investment in new equipment, exhaustion of its shallow diamond reserves, low world diamond prices, and a high Ghanaian inflation rate. Figure 1 shows the production statistics of GCD from 1923 through 1979 as related to volume of gravel treated and the average grade of the gravel. CAST remained in managerial control of GCD operations and maintained a 45-percent stake in the company until 1983 when it sold its remaining shares to the Ghanaian government.

New investment by Belgian, Indian, and Swiss companies and financial institutions in late 1984 brought loans, credit, and some new equipment to GCD operations. A new target of 1 million carats per year was established with 
a 15-year lifespan of estimated reserves (Greenhalgh, 1985). However, the new investment did not reach the targeted production goals.

In 1989, passing of the Small-Scale Mining Law led to the development of the Small-Scale Mining Project under the direction of the Minerals Commission (MC). This legislation gave the Minerals Commission responsibility for providing technical assistance to registered small-scale miners and assisting with promoting small-scale mining activities. The law was designed to allow small-scale miners to apply for a permit to mine a plot of land not yet held by another company or individual. By 2001, nine small-scale licenses were active for diamond mining (Amankwah and Anim-Sackey, 2003).

In 1991, GCD announced that an 80 -percent stake in the mine would be sold to a joint-venture between Lazare Kaplan International (LKI) of the United States and Inco Ltd. of Canada, but Inco dropped out of the venture in early 1993 (Coakley, 1995). Ghanaian Parliament approved a joint-venture option agreement between LKI and De Beers Centenary AG of Switzerland in 1993 which was designed to rehabilitate the mining equipment, manage operations, and market GCD diamonds. Mining production increased in 1994 as a result of some of the improvements, but De Beers withdrew from the project in 1995 after conducting further feasibility studies (Coakley, 1995).

By September 2007, GCD had been placed in divestiture and closed down. Currently, the Government of Ghana is seeking an investor in GCD operations (McCready, 2006).

The majority of Ghana's current diamond production is from small-scale miners and tributers. Small-scale miners are permitted to mine on land that is sold or leased to them by the Minerals Commission of Ghana. The small-scale miners often employ excavating equipment and gangs of diggers to access and wash the diamondiferous gravels. Tributers are artisanal miners licensed by GCD to dig on the company's concessions in areas not suitable for large-scale production. Theoretically, tributers sell their diamonds to GCD, but often this production is sold to registered traders because of the lack of financial capital at GCD. Galamsey is a term for unregistered small-scale and artisanal miners. Originally, the word came from a contraction of the term "get and sell," but it is now used to describe the artisanal miners who operate without licenses on concessions owned by the government or private companies.
Table 1 shows recorded Ghanaian diamond production from 1920 to 2008. Peaks in production occur from 1934 to 1940 and then again from 1949 through 1981. There is a noticeable decline from previous years for the period 1982 through 1997, which corresponds with the decline in efficiency and production of the GCD operations at Akwatia. From 1982 to 1997, Ghana averaged 603,788 carats per year in production. Production from 2000 to 2008, the most recent date for which data were available, shows an average of 920,000 carats per year. In total, Ghana has produced over $105,000,000$ carats since 1920 .

Table 1. Annual diamond production in Ghana from 1920 to 2008.

[* Source: Minerals Commission; ** Source: Kimberley Process Statistics; na, not available]

\begin{tabular}{rr|rc|cc}
\hline Year & \multicolumn{1}{c|}{ Carats } & Year & Carats & Year & Carats \\
\hline 1920 & 220 & 1950 & 978,380 & 1980 & $1,469,910$ \\
1921 & 1,790 & 1951 & 935,630 & 1981 & $1,016,580$ \\
1922 & 5,000 & 1952 & $1,784,320$ & 1982 & 893,020 \\
1923 & 15,690 & 1953 & $2,091,110$ & 1983 & 529,770 \\
1924 & 30,420 & 1954 & $2,083,040$ & 1984 & 450,050 \\
1925 & 61,380 & 1955 & $2,234,570$ & 1985 & 505,300 \\
1926 & 152,150 & 1956 & $2,226,970$ & 1986 & 878,940 \\
1927 & 340,020 & 1957 & $2,732,010$ & 1987 & 435,900 \\
1928 & 501,450 & 1958 & $3,152,090$ & 1988 & 277,970 \\
1929 & 686,070 & 1959 & $2,968,070$ & 1989 & 285,640 \\
1930 & 716,900 & 1960 & $3,121,000$ & 1990 & 636,500 \\
1931 & 848,200 & 1961 & $3,039,770$ & 1991 & 687,740 \\
1932 & 790,740 & 1962 & $3,111,800$ & 1992 & 656,420 \\
1933 & 863,720 & 1963 & $2,879,250$ & 1993 & 590,840 \\
1934 & $1,142,270$ & 1964 & $1,922,710$ & 1994 & 757,990 \\
1935 & $2,172,560$ & 1965 & $2,574,590$ & 1995 & 530,270 \\
1936 & $1,523,910$ & 1966 & $2,767,510$ & 1996 & 714,740 \\
1937 & $1,478,820$ & 1967 & $1,883,880$ & 1997 & 829,520 \\
1938 & $1,380,340$ & 1968 & $3,402,430$ & 1998 & na \\
1939 & $1,473,130$ & 1969 & $1,676,190$ & 1999 & na \\
1940 & 869,840 & 1970 & $2,223,150$ & 2000 & $878,011 *$ \\
1941 & 895,360 & 1971 & $1,909,306$ & 2001 & $1,090,072 *$ \\
1942 & 940,490 & 1972 & $2,717,390$ & 2002 & $963,493 *$ \\
1943 & $1,154,620$ & 1973 & $2,832,760$ & 2003 & $904,089 *$ \\
1944 & 900,770 & 1974 & $2,317,600$ & 2004 & $920,050 * *$ \\
1945 & 862,020 & 1975 & $2,648,650$ & 2005 & $1,013,600 * *$ \\
1946 & 702,010 & 1976 & $2,180,210$ & 2006 & $972,600 * *$ \\
1947 & 675,770 & 1977 & $2,327,950$ & 2007 & $894,800 * *$ \\
1948 & 857,560 & 1978 & $1,943,710$ & 2008 & $643,300 * *$ \\
1949 & $1,028,060$ & 1979 & $1,348,080$ & & \\
\hline & & & & &
\end{tabular}




\section{Diamond Mining Organization and Flow Chain}

Nearly 75 percent of diamond mining is completed by the galamsey miners (Kimberley Process Certification Scheme, 2007). Small-scale miners represent 7 percent of production, whereas GCD tributers account for 10 percent, and GCD itself only contributes about 8 percent.

The restriction to sell diamonds only to the Diamond Marketing Board was reformed in 1992, and currently the PMMC licenses a series of buyers who are able to buy and export diamonds while adhering to KP regulations.

Galamsey either sell their diamonds to licensed buyers who hold a "red card," of whom there are 790, or licensed buyers with a "green card," of whom there are 31 (Kimberley Process Certification Scheme, 2007). Green card buyers are permitted to buy diamonds from tributers and small-scale miners. Buyers with red cards are permitted to buy diamonds from tributers and small-scale miners as well. Additionally, they are permitted to buy and sell diamonds with other red and green card buyers and can sell directly to licensed exporters in the PMMC diamond house in Accra. One buyer has a contract with GCD to buy and export its diamonds exclusively. Currently, a total of 11 licensed diamond exporters are allowed to export diamonds with KP certificates from Ghana (Kimberley Process Certification Scheme, 2007).

The total number of artisanal, small-scale, tributers, and galamsey diamond miners in Ghana is unknown. Estimates range from 3,000 to nearly 60,000 workers. Greenhalgh (1985) recorded an average of 15,250 diggers active in Ghana between 1950 and 1954 and 10,800 between 1955 and 1959 . Formally recorded numbers of diamond diggers after that period are inconsistent and generally unavailable until GCD began registering tributers on its concessions.

GCD recorded 570 licensed tributers on its concessions, but only 70 of those were found to be active in 2007 (Kimberley Process Certification Scheme, 2007) and approximately 100 were found to be active in 2008. Each tributer hires a gang of between 5 and 10 workers. The $\mathrm{MC}$ has nine registered small-scale licensees who typically hire between 5 and 20 groups of tributers, which are each composed of 5 to 10 workers (Hilson, 2001).

Galamsey make up the bulk of the diamond workers employed in the industry. The MC began registering all tributers and diamond workers in March 2008, including those formerly known as galamsey, beginning with workers in and around the Akwatia area in the upper Birim. By March 2009 the MC had 4,179 diamond workers and 241 tributers registered in the Mining Registration Database. An additional 2,000 workers were registered before the adoption of the new database software and so, as time permitted, these records were being added to the new database. The total registered number of workers and tributers as of March 2009 was 6,420 . Each registered worker or tributer receives a mining registration identification card, which is valid for 5 years. The identification card lists the person's name, identifies the person as a diamond worker or tributer, identifies the date of issue, the date of expiry, and lists the worker's main area of operation.

When the fieldwork for this project was conducted (March 2009), the MC was still in the process of registering diamond workers. Of the sites visited in 2009, 34 percent of workers observed at active mining sites had not yet been registered. These workers were located in the middle and lower Birim, and the $\mathrm{MC}$ had not visited many of these areas to conduct registration.

\section{Introduction to the Geology of Ghana}

Ghana is underlain by the West African Craton, a Precambrian basement rock, which is one of the four cratons that make up the African continent (fig. 2). These cratons came together during the Proterozoic 2.1-2.0 giga-annum (Ga) Eburnean Orogeny. The southwestern region of the West African Craton, often referred to as the Leo-Man Shield, is composed of Archean rocks which are 3.0 to $2.5 \mathrm{Ga}$ old. The eastern portion is dominated by Birimian rocks of Proterozoic age which were deposited just before and deformed during the Eburnean Orogeny, folded, intruded by granites, and metamorphosed to greenschist facies (Leube and others, 1990). The Proterozoic Birimian sequence of metasediments and metavolcanics is found throughout Ghana, Guinea, Mali, Burkina Faso, Côte d'Ivoire, and Liberia. The Birimian rocks contain many mineral deposits including primary and alluvial gold, as well as alluvial diamonds.

In Ghana, the Birimian rocks occur in sedimentary basins, which separate roughly parallel northeasterly trending volcanic belts. The rocks were deposited on deformed and metamorphosed basement rocks as sediments and volcanics in an extensive geosyncline. The sedimentary basins are composed of weathered and deformed wackes and phyllites, metamorphosed lavas, pyroclastic volcanic rocks, and granites. The upper Birimian sequence includes the metamorphosed basic and intermediate lavas and pyroclastic rocks, and the lower Birimian sequence is composed of sedimentary rocks. However, Leube and others (1990) have proposed that the volcanics and sediments are of the same age. Age dating of the Birimian rocks indicates that they are approximately 2.3-2.0 Ga old (Leube and others, 1990).

The Cape Coast type granites intruded the Birimian sedimentary basins. Granites of the Dixcove type intruded the Birimian volcanic rocks. These granites range in age from 2.1 to $2.0 \mathrm{Ga}$ and occupy large portions of both the sedimentary basins and volcanic belts but are common along the southeastern portion of Ghana just inland from Accra to Cape Coast.

The Birimian rocks were folded, intruded, and metamorphosed during the Eburnean. Then they were uplifted and eroded. Sediments eroded from the Birimian form the Tarkwaian Group and lie on top of the Birimian in a generally northeastern-southwestern-trending belt in southwestern Ghana. 

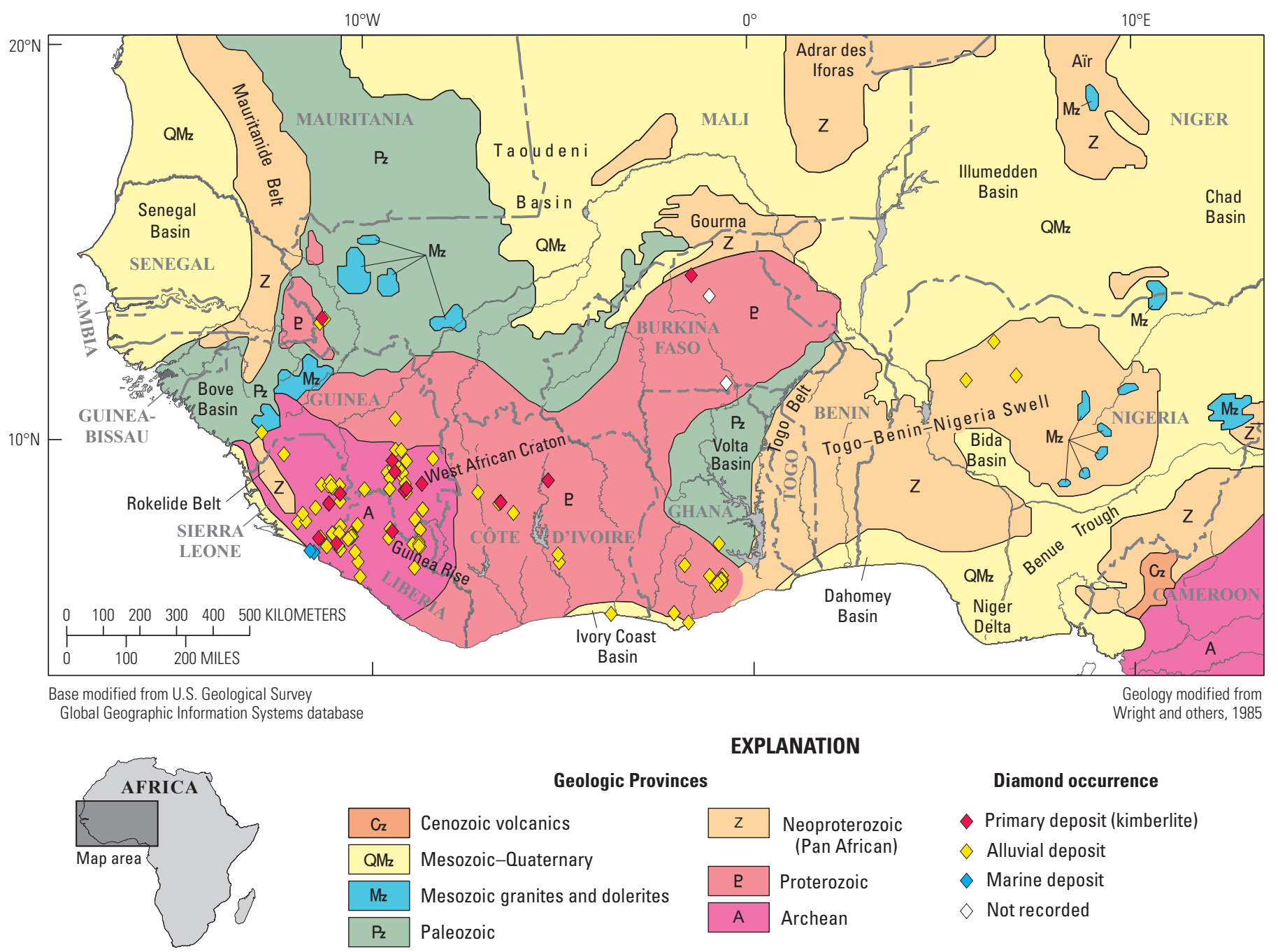

EXPLANATION

Figure 2. The geologic provinces of West Africa and diamond occurrences (modified from Wright and others, 1985).

Proterozoic to Lower Paleozoic sedimentary rocks of the Volta Basin overlie the eastern part of the West African Craton in Ghana. The Voltaian is composed mainly of very thick sandstone and siltstone. A zone of high-grade metamorphic rocks borders the Voltaian to the east. This zone is called the Dahomeyan System and comprises four lithologic belts of granitic and mafic gneiss. To the east of the Dahomeyan is a narrow zone of intensely folded and faulted rocks which form the Togo Belt. The Togo Belt is made up of multiple lithologic assemblages including quartzite, sandstone, siltstone, phyllite, and volcanics thought to be of Late Proterozoic to Early Cambrian in age.

\section{Source of Diamond Occurrences}

There are no known diamondiferous kimberlites in Ghana, and research has been conducted to identify the source of the Ghanaian diamond occurrences. Proximity to source rocks is a fundamental factor in the development of diamondiferous placer deposits. However, because of the durability of this stone, a diamond can be transported very long distances downstream to produce economical placer deposits that are up to several hundred kilometers away from the source (Teeuw and others, 1991). Ghanaian diamonds are remarkable for their small size, and also for their lack of abrasions, suggesting that they have not been transported a great distance (Appiah and others, 1996; Canales, 2005). Present theories suggest that kimberlites may have been destroyed by the Eburnean Orogeny or possibly that the kimberlitic source rocks lay underneath the thick layer of Voltaian sediments lying to the north and northeast of the Birim River drainage basin. McKitrick and others (1993) conducted geochemical analyses on an actinolite schist located in the Birim area and proposed it as the source rock for the diamonds located in the Akwatia area. Appiah and others (1996) proposed that the source of the Birim diamonds is a metamorphosed kimberlite located to the southeast of the Birim River near Akwatia. A more recent study by Canales (2005) suggested that the source of the diamonds in the Birim is not a kimberlite but rather a diamondiferous komatiite, which is similar to deposits found at Dachine in French Guiana. 


\section{Alluvial Diamond Deposits}

Diamonds have been discovered in many places in Ghana, but the two main diamond mining regions are the Bonsa River valley, near the town of Tarkwa, and the Birim River valley, mainly between the towns of Akwatia and Oda

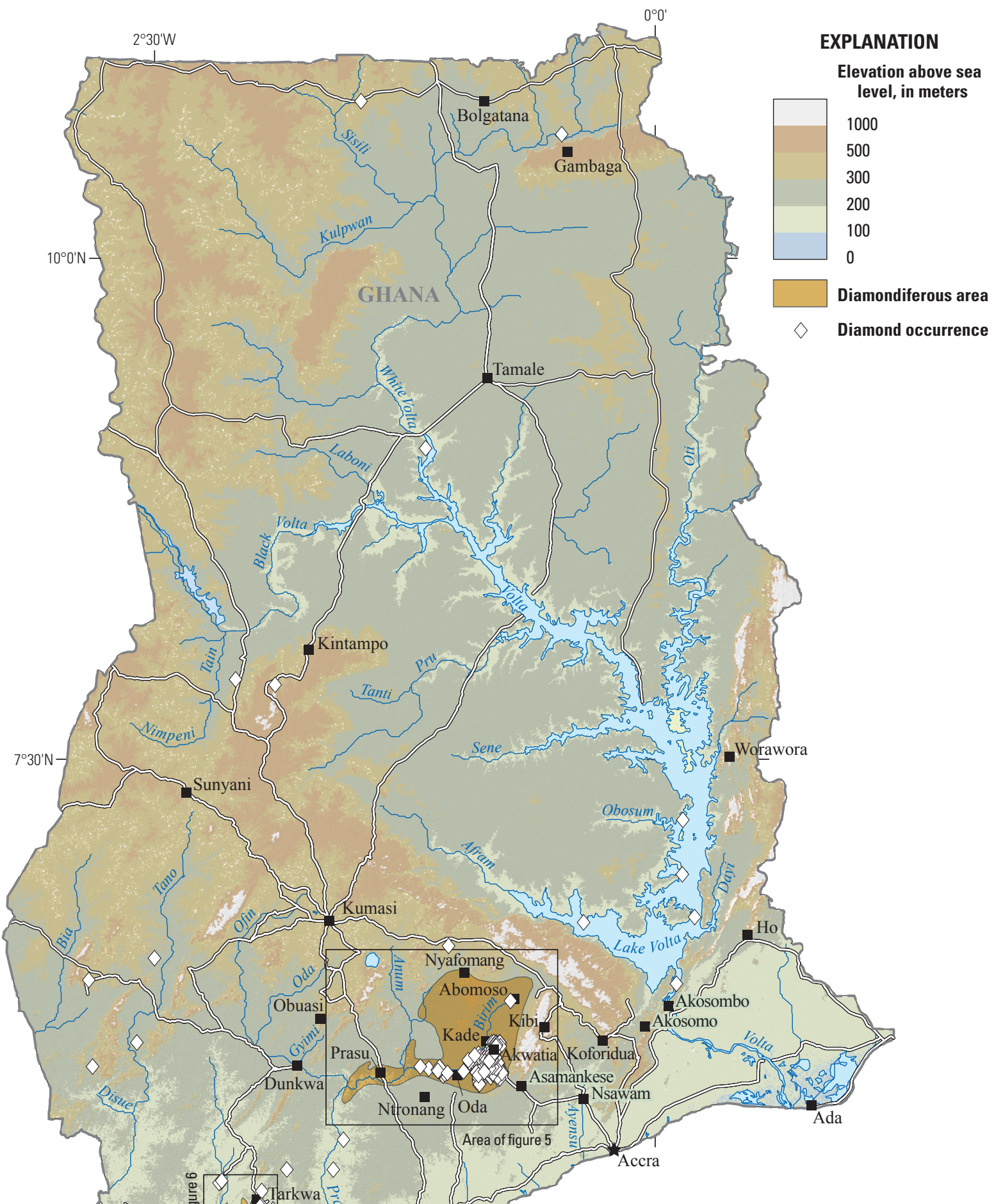

(fig. 3). The diamond resources in the Bonsa and Birim are exclusively alluvial. Alluvial diamonds are those that have been eroded from the primary source and subsequently transported and concentrated in alluvial placer deposits within the fluvial system and the surficial geologic deposits.

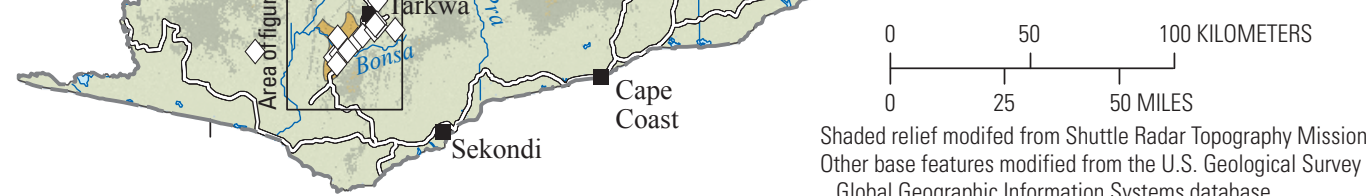

Global Geographic Information Systems database
Figure 3. The diamond mining regions and diamond occurrences in Ghana. 


\section{The Birim Diamond Field}

The Birim River originates northeast of the Atewa Range, where it flows north around the northeastern end of the range and then turns southwest. The Birim flows southwest for approximately $125 \mathrm{~km}$ where it ends in the confluence with the Pra River.

The Birim valley is underlain by metamorphic, sedimentary, volcanic, and intrusive igneous rocks of Paleoproterozoic (Birimian) age, for which the Birimian was named. To the southeast and south of the Birim valley, many areas are intruded by batholiths of Precambrian Cape Coast granite. The predominant bedrock material of the valley is composed of graywackes and phyllites, though tuffs, schists, lavas, and granitic intrusions are also common throughout the valley and form the Atewa Range to the east of the Birim.

Alluvial deposits lie on the Proterozoic rocks as a result of long-term Mesozoic domal tectonic uplift (associated with the opening of the Atlantic Ocean) and subsequent erosion and accumulation (Teeuw and others, 1991). Extensive weathering of the bedrock has created a large sediment supply to the Birim, Bonsa, and other river systems in Ghana. Weathering to depths of 27 meters (m) has been documented in and around Akwatia (Hall and others, 1985). Birimian metasediments weather to a very fine grained silty clay. The phyllites weather to clays of various colors, which can retain their banding.

The existing valleys and terraces in the Birim developed in three periods during Pleistocene to Holocene time.

Rejuvenation and subsequent erosion dissected this peneplain, established the present drainage, and reconcentrated the diamonds (Hall and others, 1985). Little detailed work has been done on the geomorphology of the Birim River alluvial deposits. Previous studies suggest that the alluvial sediments are divided into alluvial flood-plain (valley-flat sediments), low terrace, and high terrace deposits (fig. 4). In addition, laterites cap many of the high terraces, hilltops, and uplands. Long river profiles, low-gradient stream reaches, channel confluences, incised channels, and abrupt channel widening concentrate diamonds in the alluvial sediments of the river valley. Bedrock traps in the river bed are key locations for

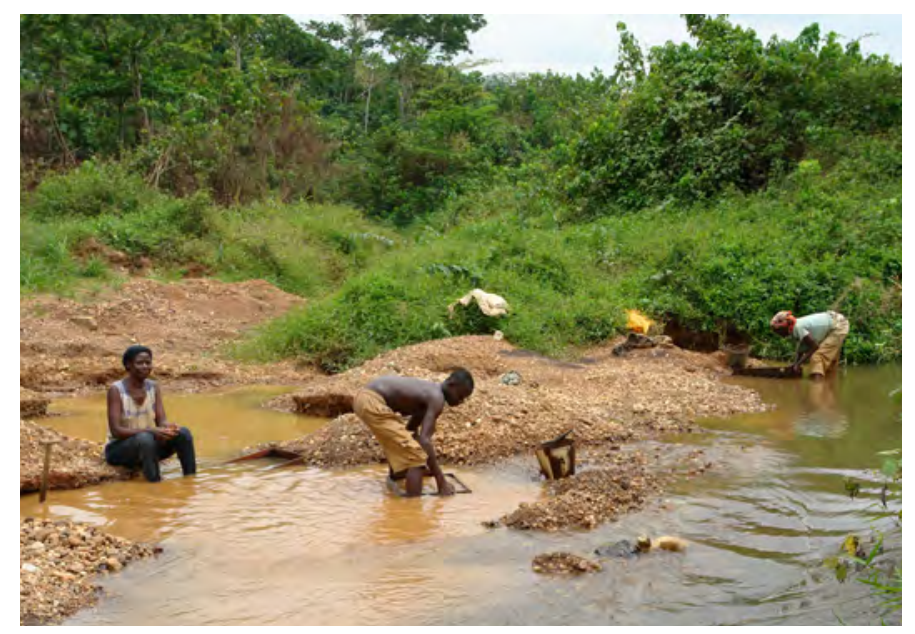

Artisanal diamond miners washing gravels in the Supong River, March 2008

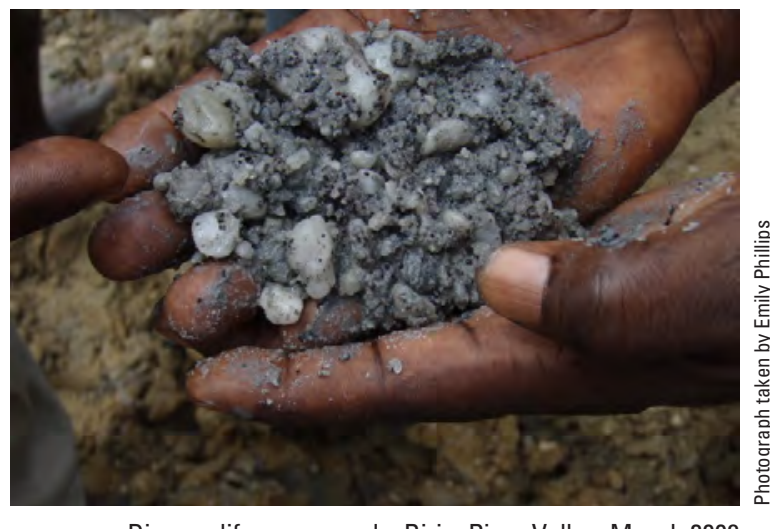

Diamondiferous gravels, Birim River Valley, March 2008

the concentration of alluvial gravel deposits. The erosion of extensive quartz veins throughout both the Birim and Bonsa River valleys contributes to a large amount of gravel-sized clasts in the surficial deposits. Often rich placer deposits are associated with course gravels, and data show that gravel size is an important indication of favorable deposits (Kesse, 1985).

Junner $(1931,1943)$ conducted much of the early work on Ghanaian diamonds and developed a basic geomorphic model of the occurrence of diamonds in valley-flat and terrace deposits. Hall and others (1985) updated the previous studies

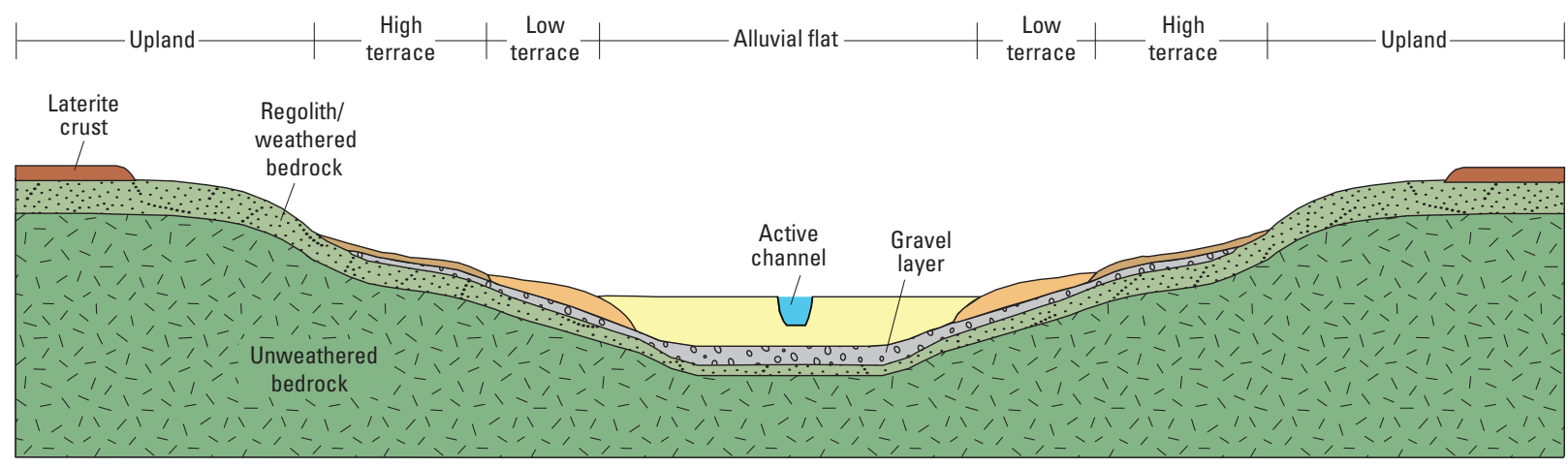

NOT TO SCALE

Figure 4. Schematic profile of flood-plain geomorphology. 
through limited field mapping and carbon-14 analyses and proposed the subdivision of terraces into high and low deposits. In addition, diamondiferous gravels were classified into three chronostratigraphic units of between 13,000 and 11,000 years before present (B.P.); 9,000 and 7,500 years B.P.; and 2,100 years B.P. to the present. Appiah and others (1996) proposed a similar model of river valley-flat deposits and terrace gravels but also found deposits on what they classified as hilltops and minor tributary valley bottoms.

\section{Diamond Mode of Occurrence in the Birim River and its Tributaries}

Diamonds are found in the gravel layers of Birim River alluvial flats, low terraces, high terraces and, to a lesser extent, uplands within the watershed. The largest and richest concentrations of diamonds are found in the deep deposits of the main Birim River flood plain, as well as valleys of very small streams, particularly those with low gradients and wide valley flats. Diamond concentration tends to decrease with increasing slope (Teeuw and others, 1991). Concentrations are high where a stream of a lower order joins a stream with a higher order when the slope is not significantly different. Diamond deposits are also found in bedrock potholes in the active channel of river beds.

The Birim diamond field has been subdivided into three sections (fig. 5). The upper Birim is made up of the diamondiferous areas just northeast of the town of Kade, south to the confluence of the Supong and the Birim Rivers. The middle Birim extends from the Supong confluence to near the town of Aduasa, where the Birim River narrows. The lower Birim extends from where the Aduasa narrows to the Birim's confluence with the Pra River.

Exploration and diamond ore estimates were completed for the Birim diamond field from the late 1960s through the late 1970s. These estimates were conducted in order to determine the future production capacity of the GCD

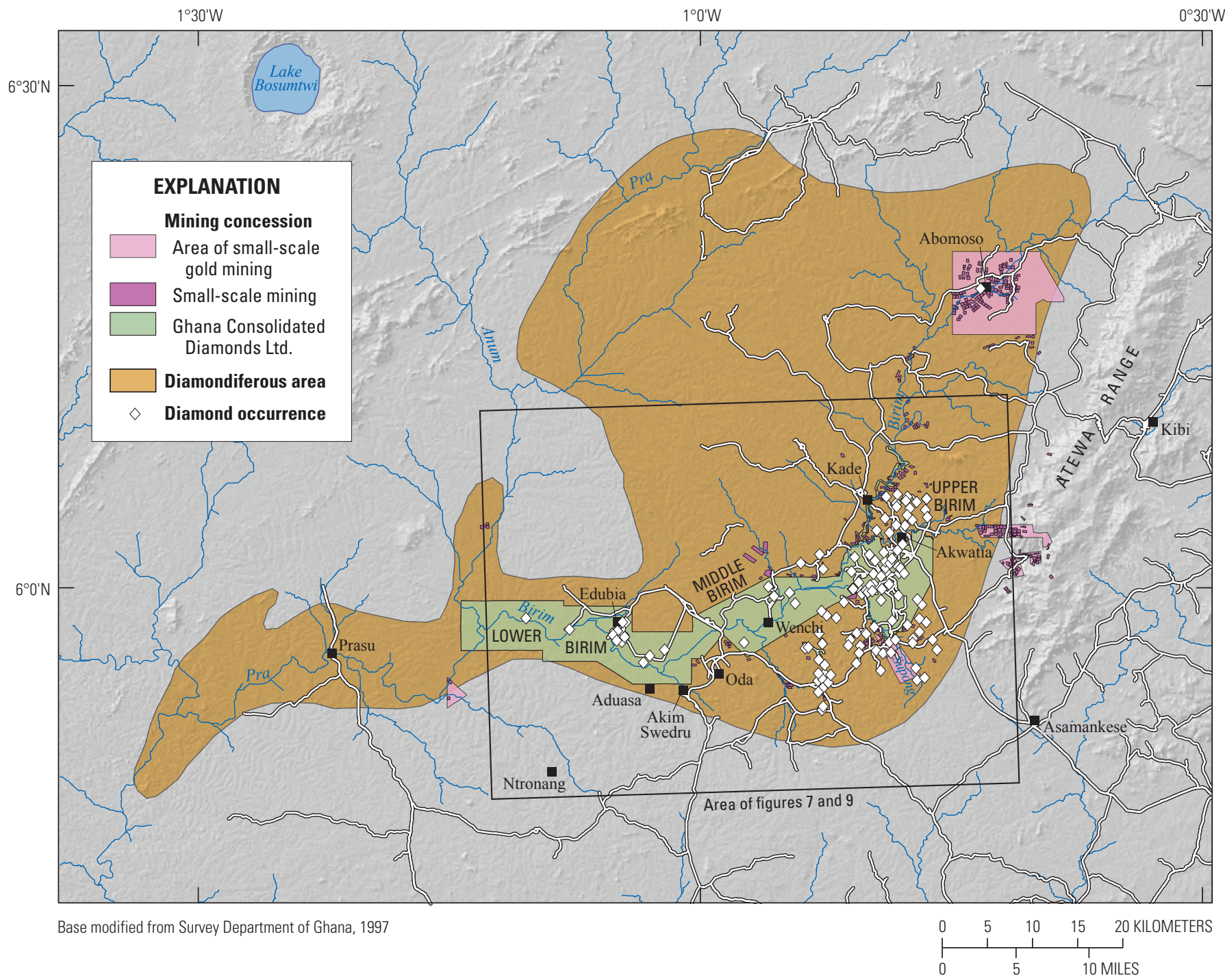

Figure 5. The upper, middle, and lower sections of the Birim diamond field. 


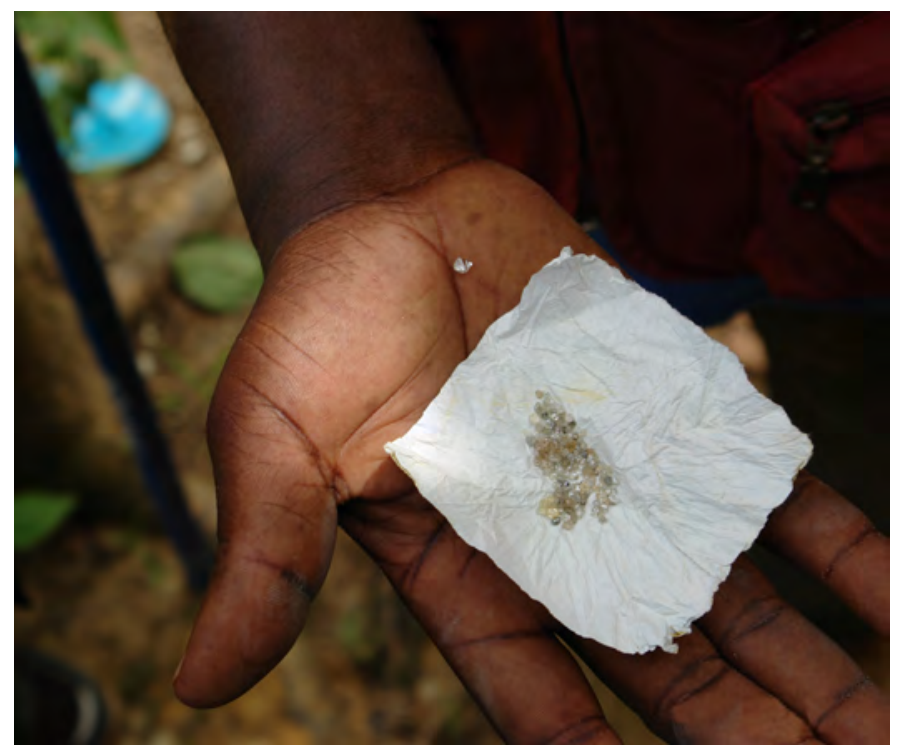

Characteristic rough diamond yield from an alluvial flat deposit in the Birim River Valley, March 2009

concession mining operations. According to Kesse (1985), the average diamond content of the gravel treated in the upper Birim field, based on GCD records, was between 1.2 and 1.9 carats per cubic yard $\left(\mathrm{kt}^{\mathrm{y}} \mathrm{yd}^{3}\right)(0.92$ to 1.45 carats per cubic meter $\left.\left[\mathrm{kt} / \mathrm{m}^{3}\right]\right)$. However, the grade of the deposits generally decreased over time from a peak of $4.87 \mathrm{kt} / \mathrm{yd}^{3}\left(3.72 \mathrm{kt} / \mathrm{m}^{3}\right)$ in $1931-32$ to $1.48 \mathrm{kt} / \mathrm{yd}^{3}\left(1.13 \mathrm{kt} / \mathrm{m}^{3}\right)$ in $1979-80$, as the rich shallow deposits were mined out (fig. 1).

Additional exploration in the upper Birim from 1969 to 1970 found promising gravel grades between the Supong River and Kade. However, with followup drilling, grades were found to be lower than expected. Nevertheless, three small economical deposits were located in this region. Akwatia reserves, also in the upper Birim, were estimated to be over 3.5 million carats.

Deposits in the middle Birim were explored with financing from the United Nations Development Programme (UNDP) from 1978 through 1981. Nine hundred twenty boreholes were drilled on the southern bank of the Birim River just southwest of the Supong confluence. Of these boreholes, two-thirds were drilled on a $240-\mathrm{m}$ grid system, and the remaining one-third drilled on a $120-\mathrm{m} \times 30-\mathrm{m}$ or alternatively a $60-\mathrm{m} \times \mathrm{6}$-m grid system in selected areas. Highly variable values of borehole gravel thickness and grade occurred with ranges from 0 to $7.65 \mathrm{kt} / \mathrm{m}^{3}$. Final results of the middle Birim exploration indicated that the average depth of alluvial overburden was $5.1 \mathrm{~m}$, the average gravel thickness was $1.95 \mathrm{~m}$, and the average gravel grade was calculated as $0.81 \mathrm{kt} /$ $\mathrm{m}^{3}$ (Ghana Consolidated Diamonds Ltd., 1982). Selected reserve blocks within this area were found to have slightly higher gravel grades, and mining ore reserves were calculated to be over 12.5 million carats.

Lower Birim deposits were also evaluated during exploration from 1946 to 1955 and then again from 1966 to 1968. The results from these exploration campaigns showed that the average alluvial overburden thickness was $5.85 \mathrm{~m}$, the average gravel thickness was $1.76 \mathrm{~m}$, and the average gravel grade was $0.78 \mathrm{kt} / \mathrm{m}^{3}$. Lower Birim deposits are the largest reserve, with over 13 million carats.

Keese (1985) estimated that over 50 million carats of reserves remain in the Birim diamond field, with over 20 million carats located within GCD concession boundaries in the upper, middle, and lower Birim sections (table 2).

Birim diamonds are characteristically small, averaging approximately 30 diamonds to the carat. Industrial grade diamonds (boart) make up 35-45 percent of those recovered. Dodecahedral crystals with curved faces are the most common, as are macles. Cubic and elongated or rod-shaped crystals are rare (Archives Rehabilitation Unit, 2003d).

Table 2. Upper, middle, and lower Birim diamond field reserve estimates based on previous reports.

[m, meter; $\mathrm{kt} / \mathrm{m}^{3}$, carat per cubic meter; $\mathrm{kt}$, carat]

\begin{tabular}{lcccr}
\hline & $\begin{array}{c}\text { Average } \\
\text { alluvial } \\
\text { thickness } \\
(\mathbf{m})\end{array}$ & $\begin{array}{c}\text { Average } \\
\text { gravel } \\
\text { thickness } \\
(\mathbf{m})\end{array}$ & $\begin{array}{c}\text { Average } \\
\text { grade } \\
\left(\mathbf{k t} / \mathbf{m}^{3}\right)\end{array}$ & $\begin{array}{c}\text { Reserves } \\
(\mathbf{k t})\end{array}$ \\
\hline Upper & 5.8 & 1.8 & $0.92-1.45$ & $3,500,000$ \\
Middle & 5.1 & 1.95 & 0.61 & $12,500,000$ \\
Lower & 5.85 & 1.76 & 0.59 & $13,000,000$ \\
\hline
\end{tabular}

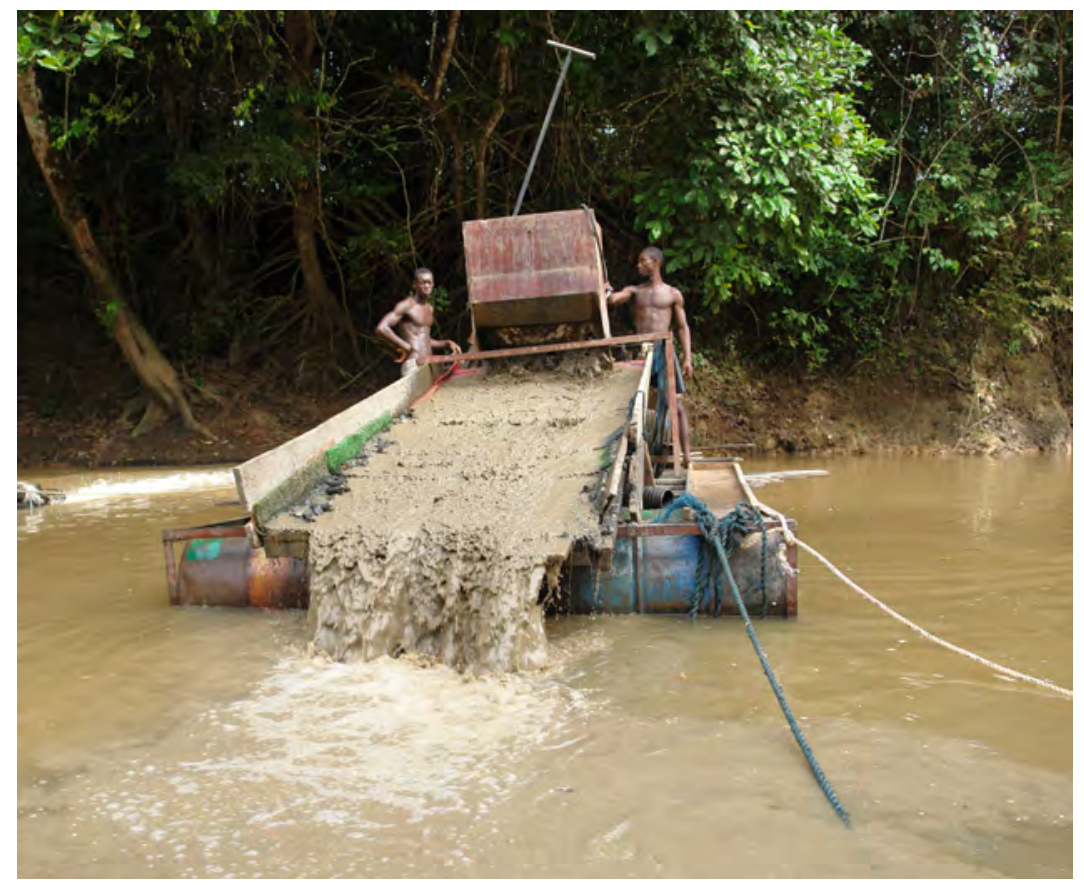

Artisanal gold dredging operations in the Bonsa River Valley, March 2009 


\section{The Bonsa Diamond Field}

The Bonsa diamond field is located to the southwest of the Birim and is also partly underlain by Birimian rocks (fig. 6). However, the Bonsa is underlain by rocks of the Tarkwaian Group. The Tarkwaian is composed of sandstones and conglomerates which have been dated at 2.0-1.95 Ga. The conglomeratic rocks of the Tarkwaian in the Bonsa River valley are the Kawere Group. The Kawere is made up of pebble-sized clasts of Birimian lavas with tourmaline and a small amount of quartz. The Kawere Group, the lowest Tarkwaian unit, underlies all the streams in the area that have been worked for diamonds. The Banket Series, which overlies the Kawere, is made up of quartzites and conglomerates and occurs near the northern edge of the Bonsa diamondiferous area.

\section{Diamond Mode of Occurrence in the Bonsa River and its Tributaries}

The physical environment of the Bonsa diamond field is similar to that of the Birim. However, alluvial deposits in the valley flats of the Bonsa tributaries are usually narrower and thinner than those of the tributaries of the Birim. The Bonsa diamond field was largely exploited by individual Ghanaian diamond miners because the diamond grades were

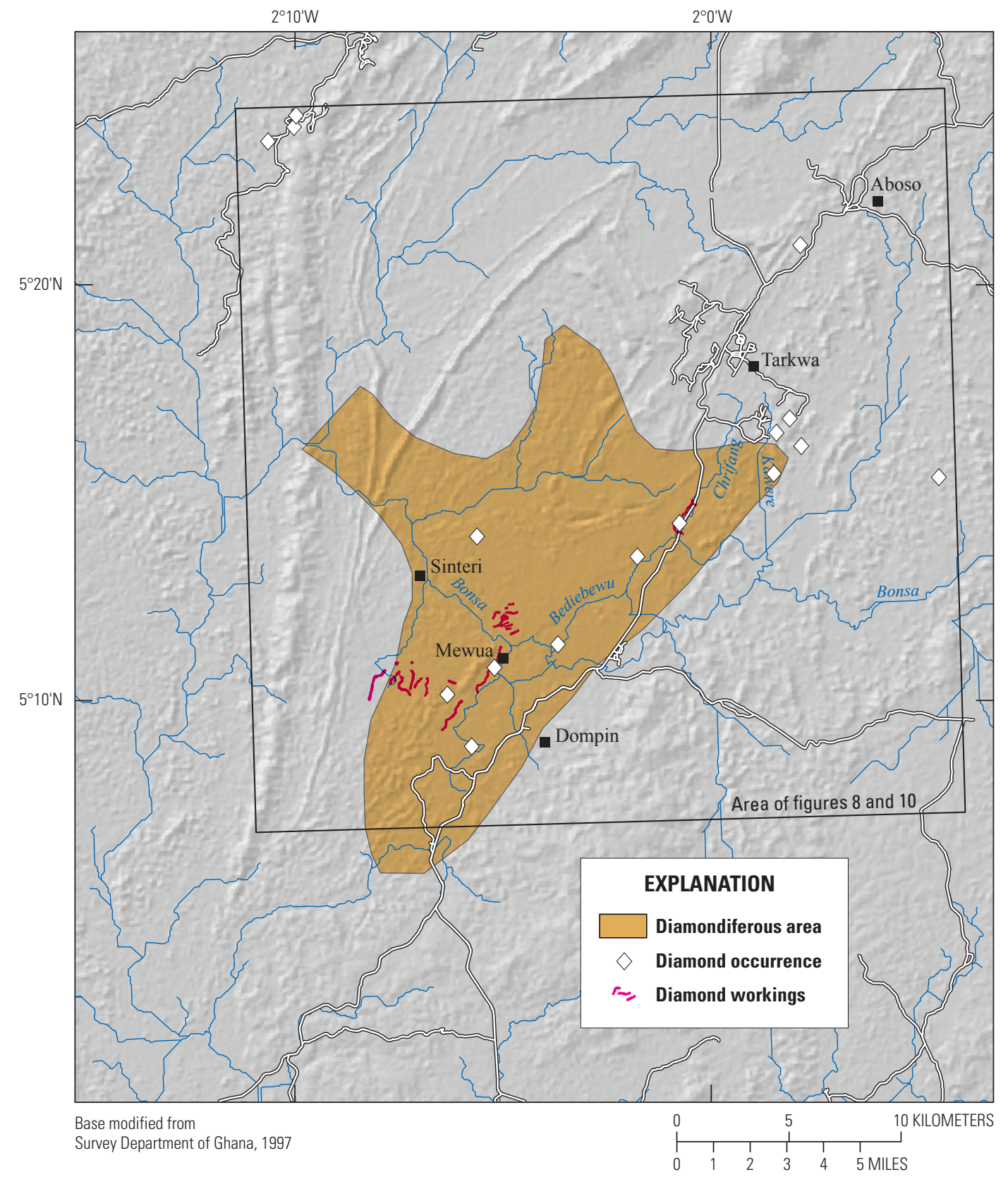

Figure 6. The Bonsa diamond field. 
irregular and commercial exploitation was rarely viable. Dunkwa Goldfields Ltd. did have a license to mine diamonds in the Bonsa for a period of time but have since moved their primarily gold-mining operation outside of the diamondiferous zones. Current diamond mining in the Bonsa is done by individuals who are rewashing the previously dredged gravel and waste materials from the gold dredging operations in the Bonsa River.

The overburden, gravel thickness, and grade of the Bonsa deposits are highly variable. The average gravel thickness ranges from $0.20 \mathrm{~m}$ to $0.45 \mathrm{~m}$, with the overburden thickness ranging from $0.6 \mathrm{~m}$ to $2.75 \mathrm{~m}$ (Archives Rehabilitation Unit, 2003a). The gravels normally consist of a mixture of subangular and rounded pebbles of quartz, tourmaline, schist, jasper, greenstone, and porphyry, derived largely from the Kawere Group conglomerates and from quartz veins in the Tarkwaian and Birimian rocks.

Diamonds in the Bonsa field average 35 stones per carat and are 40-45 percent industrial quality. Bonsa diamonds show more evidence of abrasion than do the diamonds found in the Birim field, which indicates that they have been transported farther from their primary source (Appiah and others, 1996).

The grade of the Bonsa diamond deposits is generally considered to be lower than that of the Birim, with significant exceptions where large diamonds have been recovered. Junner (1936) reported that gravels in only 3 percent of pits along the Bediebewe Stream were found to have grades higher than $0.65 \mathrm{kt} / \mathrm{m}^{3}$. Archival reports from the Geological Survey Department of Ghana indicate that some workings along the Tabu Su tributary of the Bonsa had grades of $1.09 \mathrm{kt} / \mathrm{m}^{3}$ (Archives Rehabilitation Unit, 2003a). The archival reports contain limited information on the average thickness of overburden and the thickness of gravel layers for several tributary valleys in the

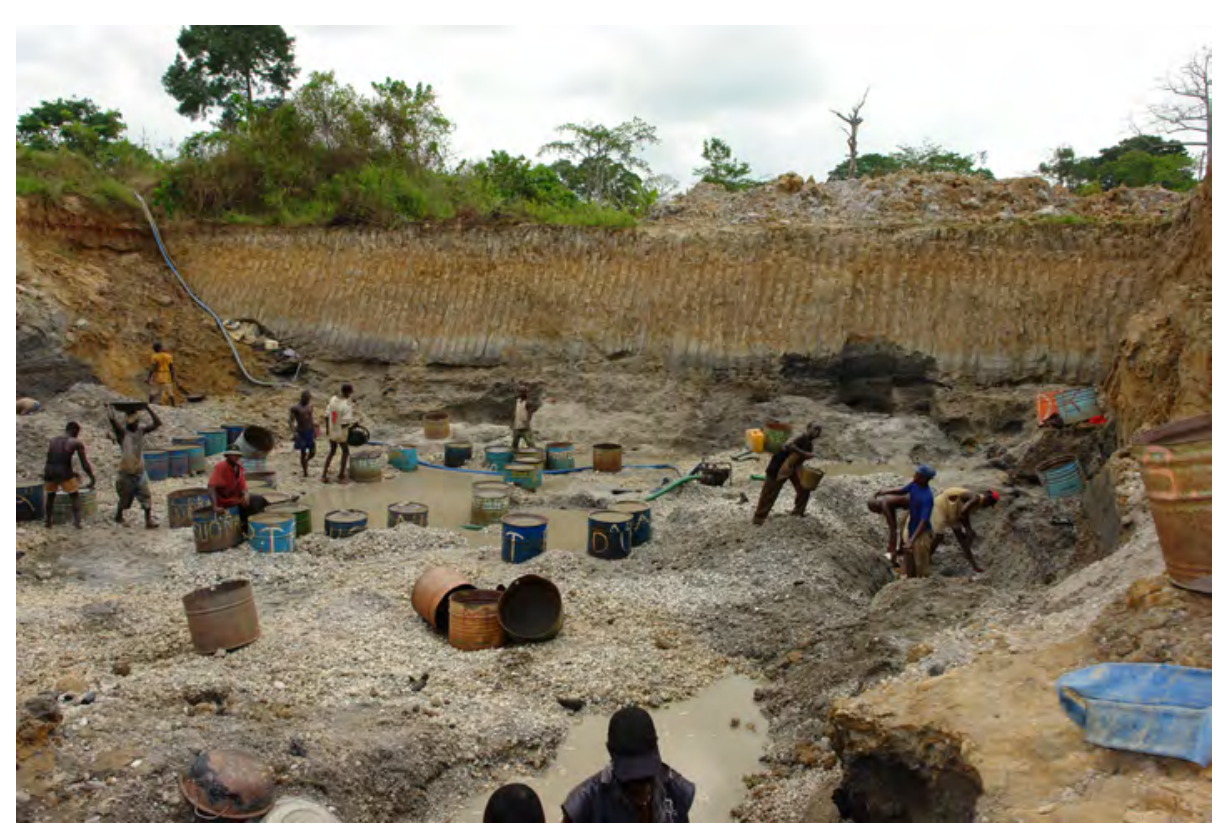

Diamond diggers removing and washing gravels, Aduasa, Birim River Valley, March 2008
Bonsa field (Archives Rehabilitation Unit, 2003a, b, c). The lack of consistent and well-documented commercial exploration or production data results in a lack of reliable grade calculations for the Bonsa.

\section{Other Diamond Occurrences in Ghana}

Beyond the Birim and the Bonsa, isolated diamond occurrences have been recorded throughout Ghana. Few of these areas have been studied systematically or evaluated further for diamond potential, even though in at least two instances diamonds have been mined by local artisans. These areas are not considered to be of economic importance at this time for the purposes of this study but are mentioned here to summarize the occurrences of diamonds in Ghana.

\section{Reported Diamondiferous Deposits}

Many diamonds have been found in the Pra River and its tributaries from the confluence with the Birim past the confluence with the Ofin River. Diamonds here occur in the alluvial flats and terraces of the Pra River but may be reworked gravel deposits of the Birim. The Nyafomang area in the Eastern Region has reportedly had several diamond discoveries, but no prospecting or reports have been completed in this area (Kesse, 1985).

Several reports were available on diamond deposits in the Western Region. Gold-mining operations have recovered diamonds as a byproduct in Dunkwa along the Ofin and Gyimi (Jimi) Rivers. In 1950, diamonds were discovered near the town of Aboso along the Kawere River valley. At the time, several scattered and small-scale alluvial workings found diamonds in $0.15 \mathrm{~m}$ to $0.30 \mathrm{~m}$ of gravel beneath approximately $0.75 \mathrm{~m}$ of overburden (Kesse, 1985).

Galamsey have reported success in finding diamonds in alluvial deposits that are also mined for gold in the Worawora area of the Volta region (University of Ghana, 1989).

\section{Isolated Diamond Occurrences}

Two small diamonds were found near the confluence of the Volta and Obosum Rivers in 1919. The Obosumanu and Afram Rivers near Mankrong (subsequently inundated by Lake Volta) were host to larger than average sized diamond discoveries (University of Ghana, 1989). A 10.5 and a 7.5 carat stone were found in the gravel layer of the White Volta near the town of Gambaga in 1936. Isolated diamonds were also found between Wenchi and Kintampo. Lake Volta, 
which was created in 1964 by the construction of a large earthand rock-filled dam at Akosombo in the Volta River Gorge, has since inundated several recorded diamond occurrences along the Volta River (Schlüter, 2006).

\section{Methodology of the Study of Ghanaian Diamond Resources}

The study of Ghanaian diamond resources consists of two components. The first requires the assessment of the naturally occurring endowment of diamonds in Ghana, which can be termed the "potential diamond resources," based on geological evidence, previous studies, and recent field data collection. The second assesses the diamond production capacity through an understanding of current human and resource conditions in Ghana and a measure of the intensity of mining activity. A degree of independent analysis can be reached by assessing both the potential resources and the production capacity and comparing these data with the published diamond production figures. The study is dependent on bibliographic research and previously published and unpublished reports, journal articles, and mining data. It is also dependent on acquiring new data in the field to assess the current situation and to gather first-hand measurements of diamond-mining activity.

Once data are gathered, several possible methods can be used to estimate the potential diamond resource. However, there is generally a lack of sufficient and consistent data recording all diamond mining activity in countries such as Ghana, where alluvial diamond deposits are common. Time to conduct fieldwork and accessibility to the diamond mining areas are limited, due to their often remote nature. Therefore, methodological models are used to estimate the potential resources. In similar studies of potential diamond resources, the two methodologies that are typically used are the volume and grade and the content-per-kilometer approaches (Barthélémy and others, 2006; Chirico and others, 2010a, b). The content-per-kilometer method develops an estimate of diamond production based on a certain productivity of carats, which is associated with the order and length of river and stream segments. The volume and grade approach uses available information on diamond ore grades and alluvial deposit geomorphology to calculate the volume of diamondiferous gravel and, using the grade, the number of carats per cubic meter.

\section{Basic Research and Bibliographic Study}

This study included the research, collection, and organization of all available data related to diamond resources and production in Ghana. This required extensive bibliographic research and collection of GIS data, geologic maps, geophysical data, and remotely sensed satellite imagery. During this phase of work, basic evaluations of the incoming data were conducted to assess their relevance, quality, and importance. Reports were examined to find all documented occurrences of diamonds and, where possible, the diamond grade was recorded for these locations.

A digital database of diamond-mining sites and areas of significant diamond workings was developed and mapped in a GIS. Sites were attributed with grade of the deposit, deposit type, thickness of overburden, thickness of gravel layer, and number of active miners. This database was used to create maps of the diamond-mining areas as well as to focus the analysis on the intensively mined zones within the two main diamondiferous zones of Ghana.

\section{Fieldwork}

The second phase of this project was field evaluation. This phase incorporated all field mapping and data collection in the Birim and Bonsa River valleys. Also included was developing contacts and working with the scientists and staff of the cooperating agencies in Ghana including the Ministry of Land, Forests, and Mines; the Minerals Commission; the Geological Survey Department; and the Precious Minerals Marketing Company.

Field mapping was conducted during March 2008 and March 2009. During each of the field seasons, current and historical areas of alluvial mining were visited. At each site new database records were developed that cataloged the relevant geologic information as well as data related to the number of

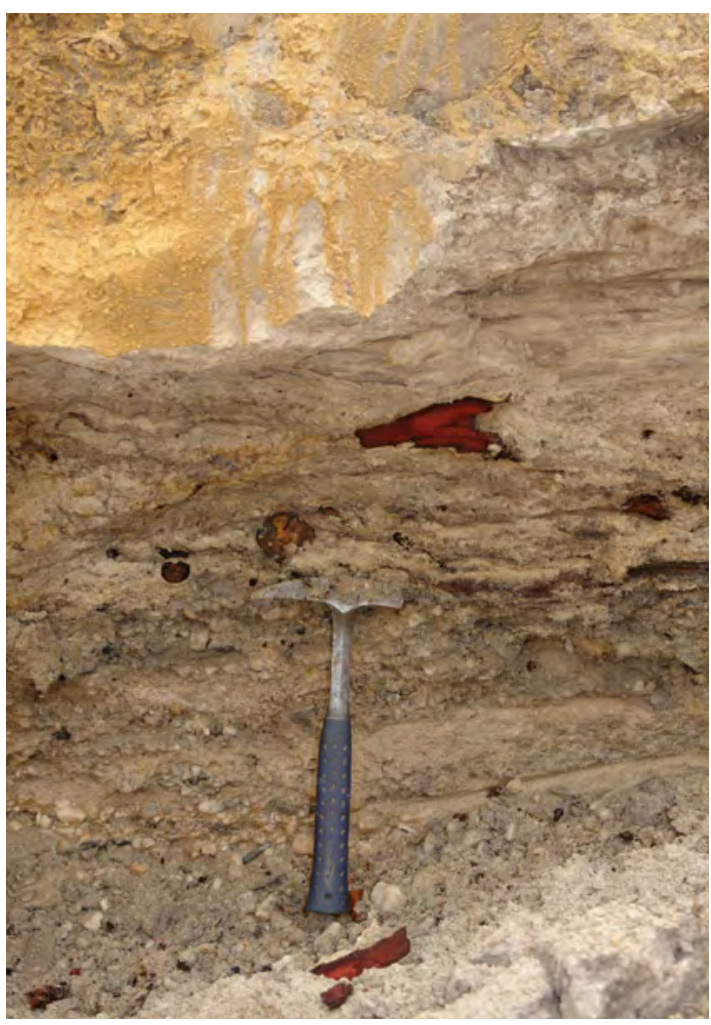

Example of organic material lying above the diamondiferous gravel layer at Akwatia, Middle Birim, March 2009 
miners, the seasonality of the mining activity, and the yield or grades of the diamondiferous deposits. Information about the productivity of diamond workings and the amount of overburden at specific sites was measured and recorded. Site visits revealed the nature of the diamond deposit, the thickness of the gravel layers being mined, and the geomorphologic deposit type.

At 12 sites, detailed geological profiles were measured and mapped from alluvial mining pits. At these locations detailed graphical profiles were constructed to catalog the thickness of the gravel layer and its relation to the thickness of overburden. A global positioning system (GPS) receiver was used to record the geographic coordinates of all of the sites.

To accurately and uniformly gather the information from the field, a comprehensive questionnaire was developed and used in gathering the information. The field team carried a set of questionnaire booklets that contained blank forms which the field team filled out at every site that was visited during the field study. Spatial location (longitude and latitude) of the mine sites, and mine conditions were recorded accurately. Mine conditions may have included the size and depth of the mine, the distance from the closest river, town, and road, the depth of the overburden, and the thickness of the gravel. In addition, questions were asked regarding the flow of production, number of miners and teams, and additional jobs occurring in the surrounding areas. The standardized questionnaire ensured that consistent data were gathered at each site, even though the teams were working separately at different sites throughout the country. The field data gathered through this method were incorporated into the database of diamond occurrences.

\section{Geochronology and Carbon-14 Dating of Samples}

Organic matter was sampled from geological profiles at four of the alluvial diamond sites. These samples were processed at the carbon-14 laboratory of the U.S. Geological Survey in Reston, Virginia. Ages of the samples were reported in radiocarbon years (B.P.) using the Libby half-life of 5,568 years. The geochronologic dates were then compared to previous studies of the Birim alluvial deposits to assist with classification of the deposits into a chronostratigraphic framework.

\section{Methodology to Estimate the Diamond Potential of Ghana}

For this study a modified version of the volume and grade approach was used (Barthélémy and others, 2006). The modified approach uses digital maps of geomorphology to derive the area measurements of the alluvial deposits. The methodology relies on a GIS and terrain modeling to map geomorphology of the alluvial flats, terraces, and upland areas within watershed boundaries for diamondiferous rivers and streams. Further, this methodology assesses average gravel thickness, volumes, and grades, for each of the geomorphic deposit types modeled in the GIS. The data were used to calculate a total diamond reserve, which is the number of carats of diamonds estimated to be located in the diamondiferous watershed subbasins in the Birim and Bonsa. In the final step, the total amount of diamonds that have already been produced was subtracted from the reserve calculation to estimate the total remaining reserve in Ghana. For the purpose of this study, 90 percent of the 105,000,000 carats produced is estimated to have come from the Birim diamond field and the remaining 10 percent from the Bonsa. Using these percentages of the total Ghanian production, 94,500,000 carats are assumed to have been mined from the Birim deposits and $10,500,000$ carats are assumed to have been produced from the Bonsa field. The final result of this assessment is compared to previously reported calculations of diamond reserves within Ghana.

\section{The Deposit Types}

Diamonds are found in several different alluvial deposit types in both the Birim and Bonsa River valleys. These deposits have different gravel thicknesses and different diamond grades. Modeling the deposit types separately helps to calculate the potential diamond reserves more accurately. The alluvial diamond deposits may be separated into four distinct geomorphologic types: the alluvial flat, the low terrace, the high terrace, and the upland deposit (fig. 4). The modified volume and grade approach uses a digital geomorphic map of deposit types to calculate the surface area of the deposit and then uses the average grade per deposit type to calculate the potential reserves within each unit.

\section{Digital Geomorphic Map}

Geomorphology of deposit types was mapped through a combination of field mapping and digital terrain modeling in a GIS using a digital elevation model (DEM) and the hydrologic network. Alluvial relief and path-distance functions were combined to create maps of the Birim and Bonsa River valleys showing alluvial flats, low terraces, high terraces, and uplands (figs. 7 and 8). Field mapping was composed of traditional geomorphologic mapping of surficial deposits based on profiles at 12 sites where active diamond diggings were recorded. At these profile sites, detailed data on thickness of overburden, thickness of gravel, elevation above the closest river or stream channel, and the characteristics of the gravel itself were recorded and attributed to the geomorphology of the deposit. At numerous additional sites GPS measurements were taken and data were recorded describing the local geomorphology, proximity to stream or river, and elevation above the river. 


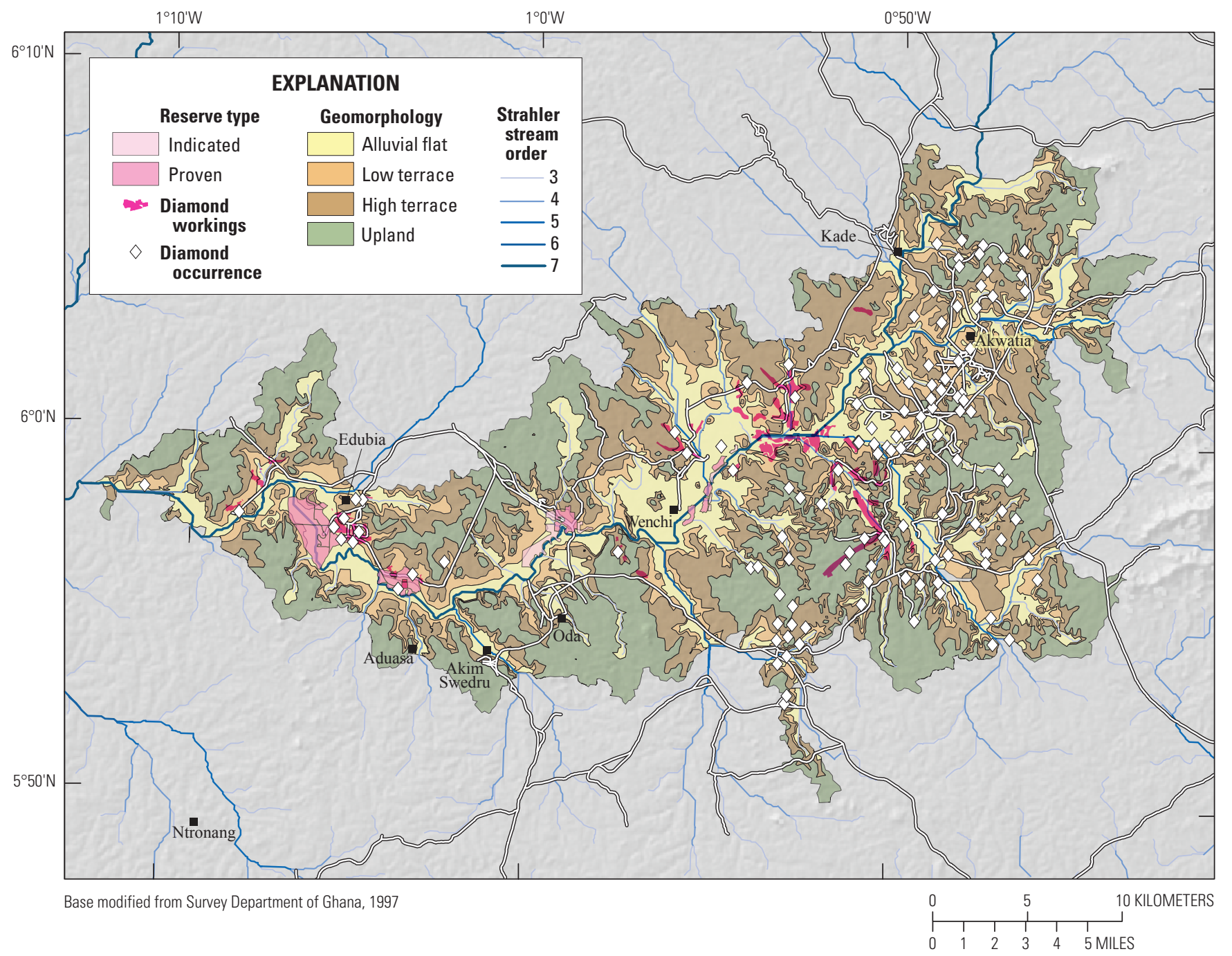

Figure 7. The surficial geomorphology of the Birim diamond field.

\section{Subbasin Watershed Analysis}

Although diamonds have been found throughout each of the two river valleys, it is unlikely that the entire watershed is equally endowed with viable diamond deposits. Historical research demonstrates that the concentration of diamonds occurs in specific sub-watershed basins of the tributary reaches and of the main Birim and Bonsa. For the purposes of this study, only subbasins of the Birim and Bonsa that have recorded diamond occurrences within them are estimated to be diamondiferous. A GIS layer was developed showing subbasins of the Birim and Bonsa for which one or more records exist that show diamond occurrences or diamond workings. The diamond potential analysis was performed on the diamondiferous subbasins layer. The subbasin layer was developed using a watershed modeling function in the GIS which determines subbasins according to the Strahler streamorder system (Strahler, 1964).

Stream ordering is a process whereby a river system channel network map is analyzed quantitatively. The smallest tributaries in the uppermost portions of a watershed are assigned an order of 1 . They are the smallest and shortest segments of the riverine network. When two first-order streams come together, a second-order stream is formed. Only when two second-order streams join is a third-order stream formed. This analysis continues until all streams and river channels in the network have been classified. The logic behind the stream-ordering system developed by Strahler (1964) is that the order number is directly proportional to the size of the contributing watershed, to channel dimensions, and to stream-discharge measurements for each stream segment. The nature and extent of alluvium in the Birim and Bonsa River 


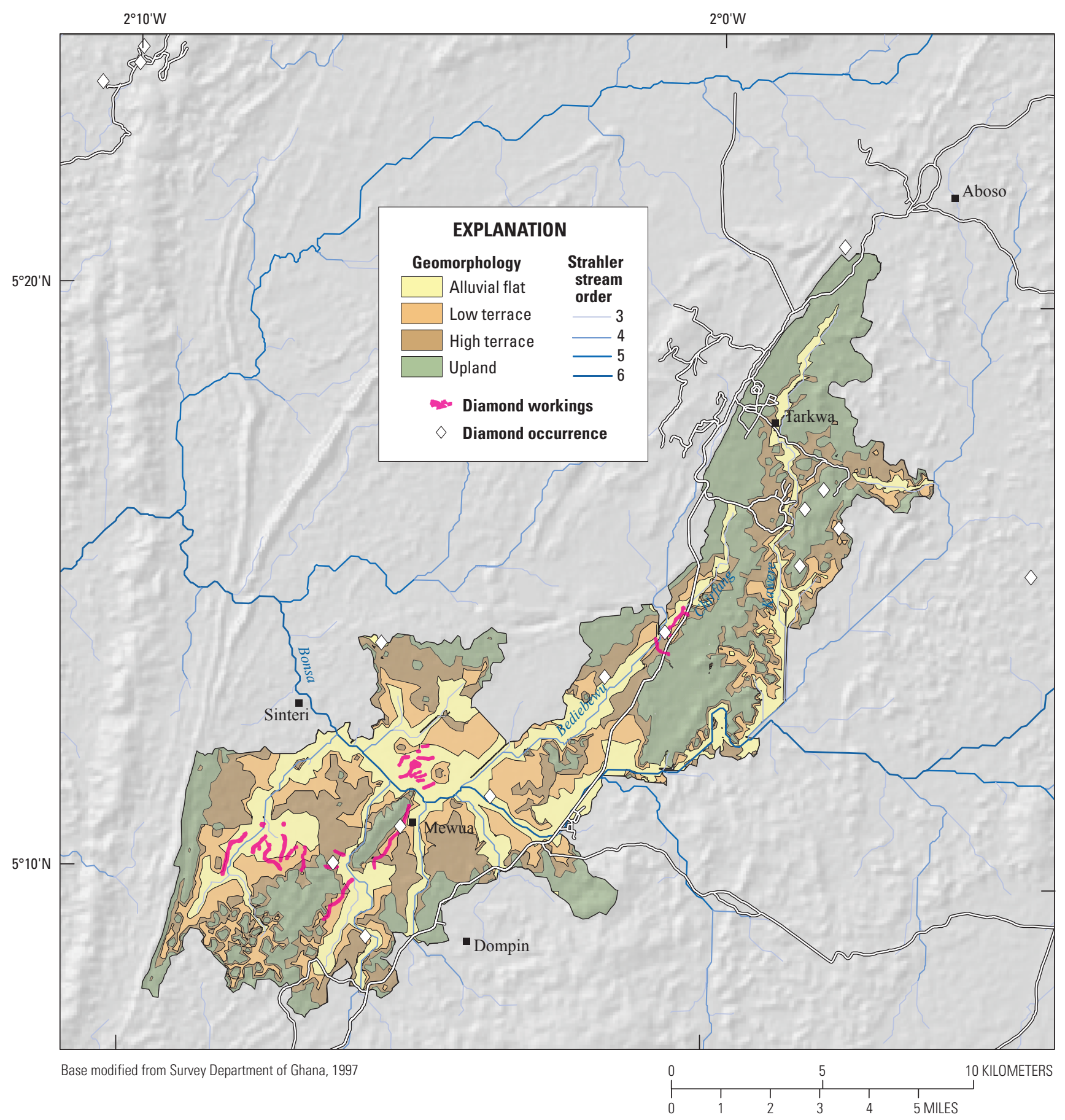

Figure 8. The surficial geomorphology of the Bonsa diamond field. 
valleys varies and is related to the stream order of the river or tributary (Archives Rehabilitation Unit, 2003d). The main Birim and Bonsa Rivers have thicker and wider alluvial flats, whereas the tributaries have generally thinner and narrower alluvial sediments. In this study, subbasins were developed for Strahler order 3 and higher stream segments. Subbasins for the Birim and Bonsa were then intersected with the GIS layer of diamond occurrences to select a subset of the basins that could be considered diamondiferous (figs. 9 and 10).

\section{Modified Volume and Grade Approach}

In its simplest form, the volume and grade methodological approach can be expressed mathematically as:

$$
P=(V G),
$$

where
$P \quad$ is the estimated diamond resource potential,
$V \quad$ is the volume of the deposit, and
$G \quad$ is the grade in carats per cubic meter.

The volume of the deposit is determined, in this method, by calculating the surface area of the different geomorphic deposit types and multiplying them by the thickness of the gravel layer documented for each type of deposit. The gravel thickness is determined by averaging thickness measurements from the database and from new field data collected.

The surface area of each of the deposit types was calculated for the diamondiferous part of the Birim and Bonsa watersheds. For each deposit type an average gravel thickness was developed from the diamond occurrence database and from previous reports. Similarly, an average gravel grade was developed for the deposit types in the Birim by intersecting the diamond occurrence database points with the geomorphic deposit type map. A total of 54 points in the database have reliable grade information for diamond-mining sites in the Birim. An average grade was developed for each deposit type (alluvial flat, low terrace, high terrace, and upland) by intersecting points with grade information (fig. 11). Alluvial flats have been calculated to have an average grade of $0.78 \mathrm{kt} / \mathrm{m}^{3}$. Low terraces and high terraces have been calculated to have an average grade of $0.436 \mathrm{kt} / \mathrm{m}^{3}$ and $0.299 \mathrm{kt} / \mathrm{m}^{3}$, respectively.

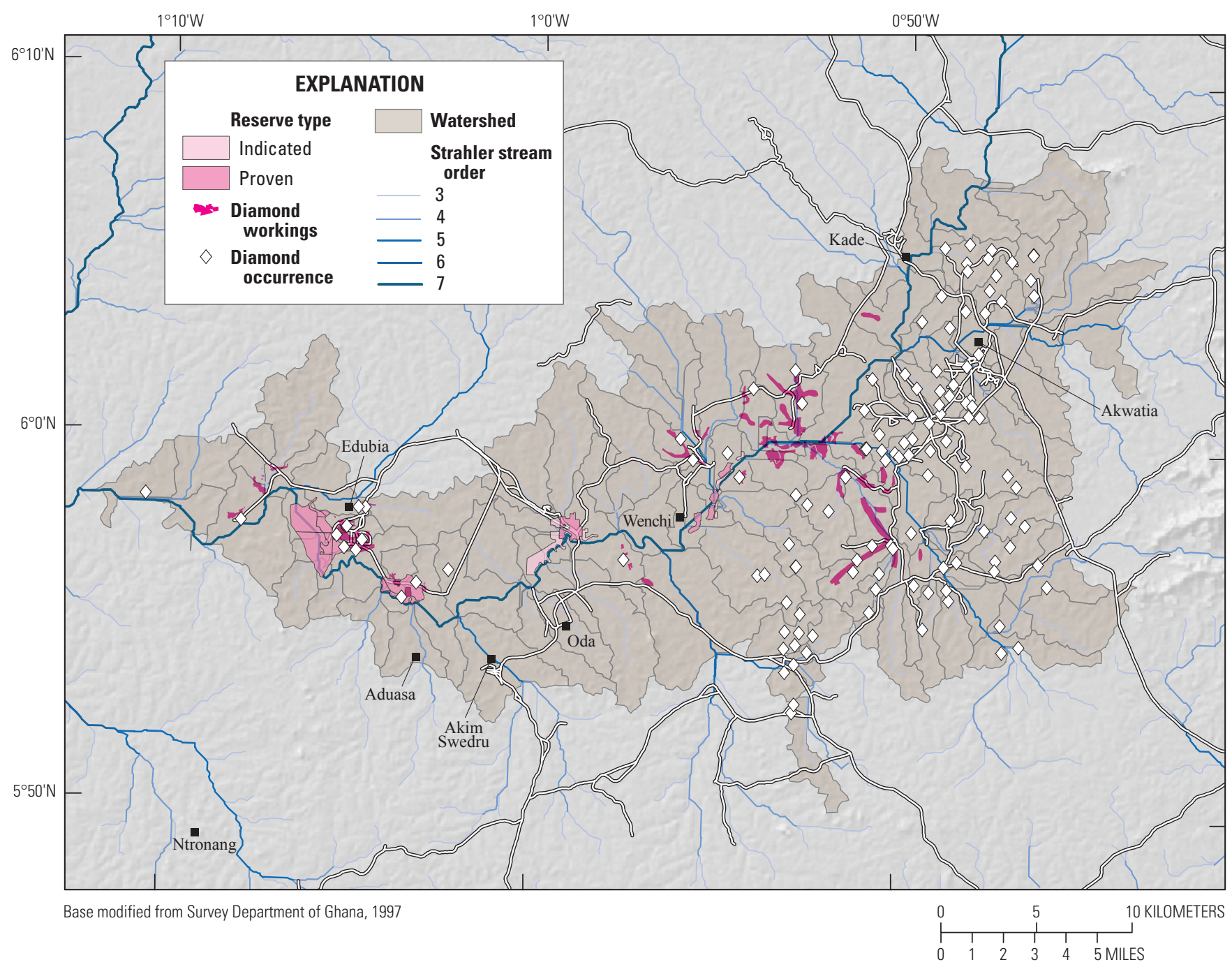

Figure 9. Calculated diamondiferous subbasins of the Birim diamond field. 


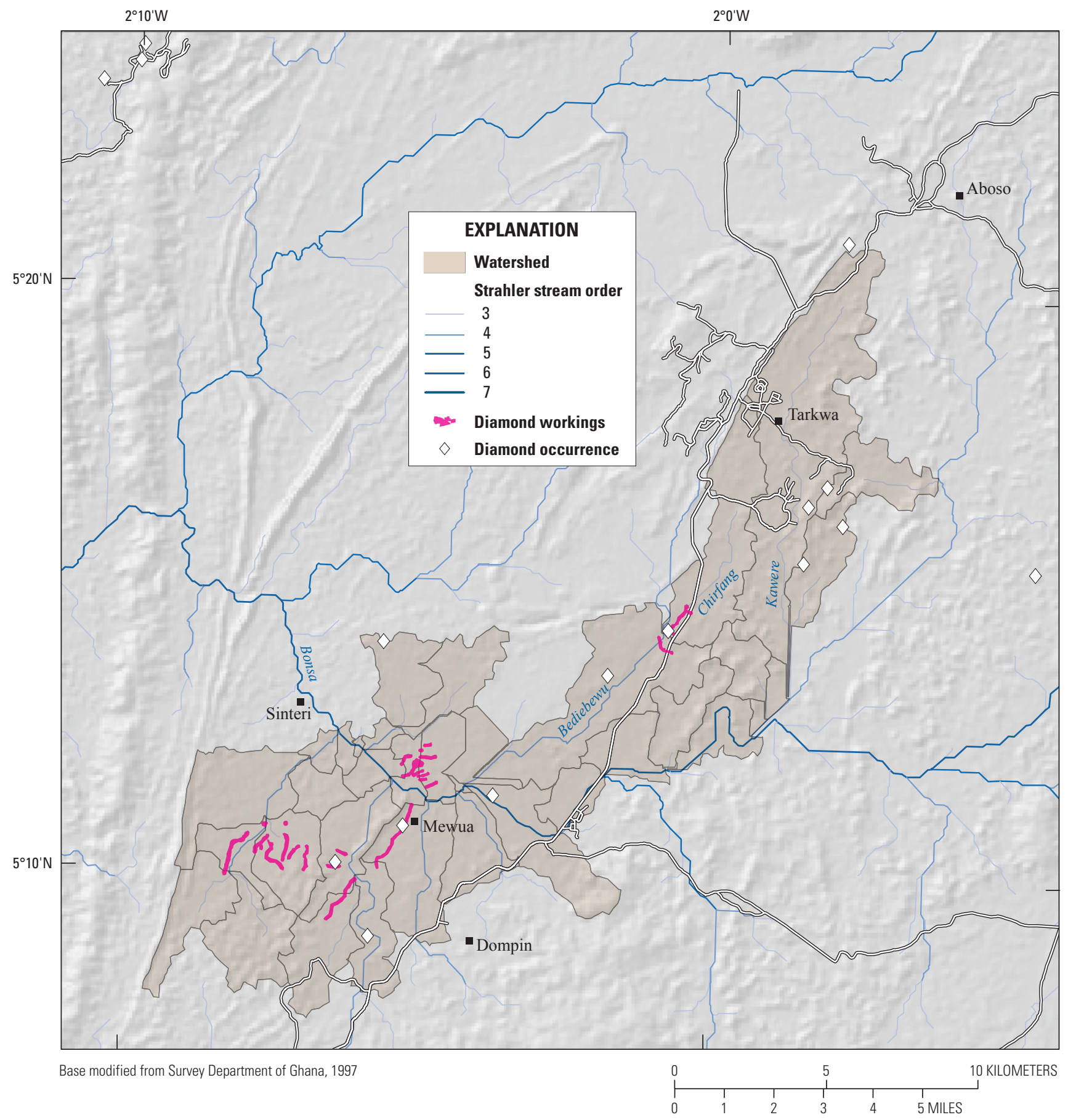

Figure 10. Calculated diamondiferous subbasins of the Bonsa diamond field. 


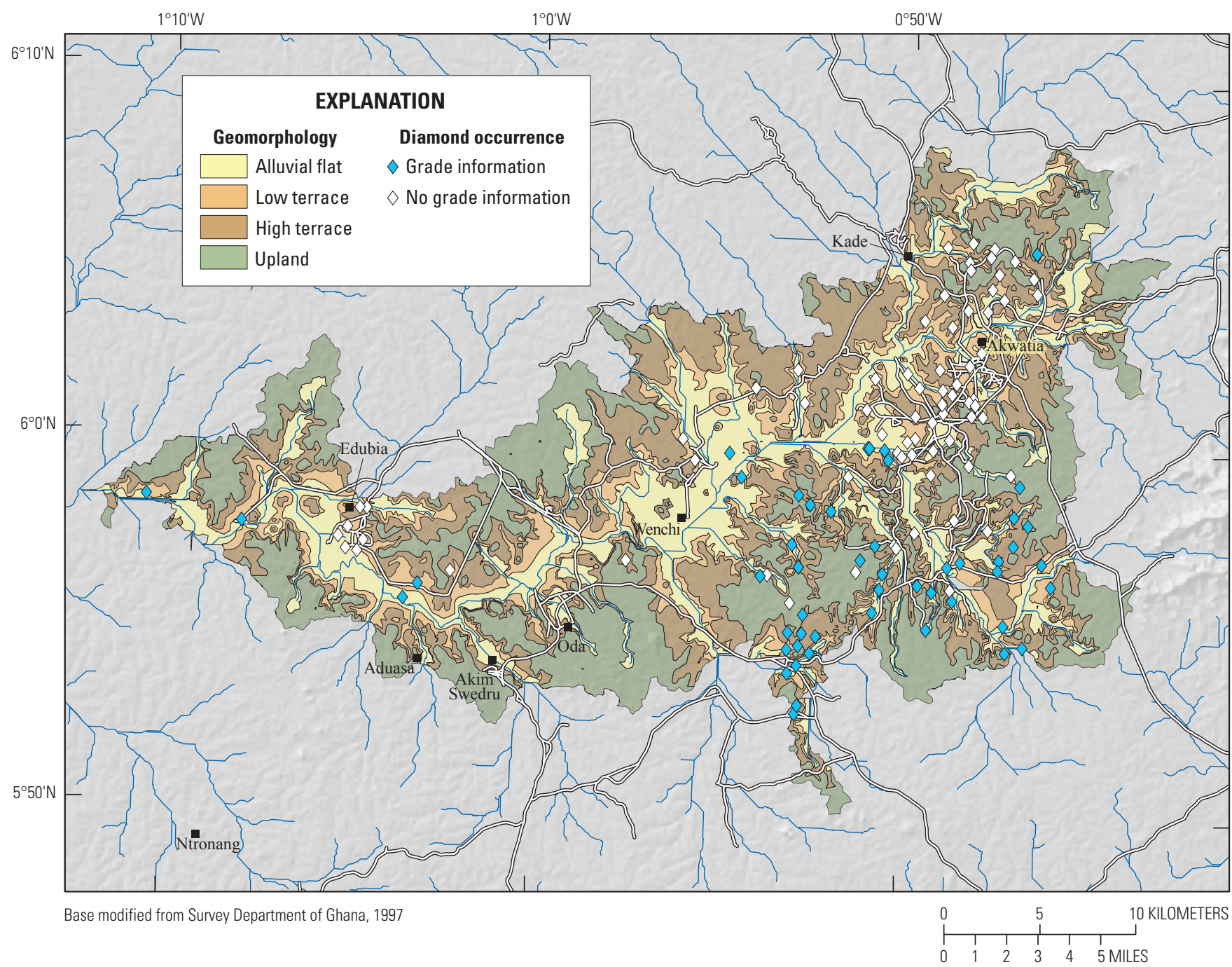

Figure 11. The surficial geomorphology diamond database occurrences having reliable grade information, Birim diamond field.

Uplands in the Birim are calculated to have an average grade of $0.16 \mathrm{kt} / \mathrm{m}^{3}$.

Only four sites had grade data in the Bonsa area, and these data were determined to be unreliable. Therefore, for the Bonsa, information from the various reports and documents has been used to infer an estimated grade for the deposits. Alluvial flat deposits are estimated to have an average grade of $0.5 \mathrm{kt} / \mathrm{m}^{3}$; lower terrace deposits are estimated to have an average grade of $0.25 \mathrm{kt} / \mathrm{m}^{3}$; high terrace deposits are estimated to have an average grade of $0.125 \mathrm{kt} / \mathrm{m}^{3}$, and uplands are estimated to have an average grade of $0.05 \mathrm{kt} / \mathrm{m}^{3}$.

Table 3 shows the grade and geomorphic deposit types modeled in this study for sites in the Birim, and table 4 shows the same data for sites in the Bonsa. 
Table 3. Average grade of Birim River diamond deposits by geomorphic type.

[* Isolated diamond occurrence; $\mathrm{kt} / \mathrm{m}^{3}$, carat per cubic meter]

\begin{tabular}{|c|c|c|c|c|}
\hline Number & Latitude & Longitude & Stream & Grade $\left(k t / m^{3}\right)$ \\
\hline \multicolumn{5}{|c|}{ Alluvial Flat } \\
\hline 1 & 5.9857558333 & -0.9062236111 & Birim & 1.09 \\
\hline 2 & 5.9964661111 & -0.9118177778 & Birim & 1.33 \\
\hline 3 & 6.0002291667 & -0.8494997222 & Supon & 1.85 \\
\hline 4 & 5.9995466667 & -0.8419508333 & Supon & 1.89 \\
\hline 5 & 5.9952972222 & -0.8401205556 & Supon & 2.35 \\
\hline 6 & 6.000 & -0.849 & Supon & 1.18 \\
\hline 7 & 5.927 & -1.058 & Birim & 1.72 \\
\hline 8 & 5.901 & -0.879 & Sebum & 0.07 \\
\hline 9 & 5.907 & -0.873 & Danyame & 0.24 \\
\hline 10 & 5.956 & -0.883 & Sensenkwakwa & 0.37 \\
\hline 11 & 5.944 & -0.841 & Tropea & 0.51 \\
\hline 12 & 5.937 & -0.843 & Tropea & 0.06 \\
\hline 13 & 5.936 & -0.819 & Awolorso & 0.23 \\
\hline 14 & 5.919 & -0.821 & Awolorso & 0.03 \\
\hline 15 & 5.898 & -0.883 & Bimpon & 0.41 \\
\hline 16 & 5.971 & -0.783 & Santra Mo tributary & 0.07 \\
\hline 17 & 5.947 & -0.812 & Santra Mo & 0.12 \\
\hline 18 & 5.971 & -0.865 & Aboabo & 0.32 \\
\hline 19 & 5.960 & -1.131 & Birim & 1.00 \\
\hline Average gi & de values for al & ial flat deposits & & 0.78 \\
\hline \multicolumn{5}{|c|}{ High Terrace } \\
\hline 1 & 5.9458161111 & -0.8794272222 & Sensenkwakwa & 1.70 \\
\hline 2 & 6.0901327778 & -0.7756405556 & Anyinasu and Abusukutu & 0.74 \\
\hline 3 & 6.0901327778 & -0.7756405556 & Anyinasu and Abusukutu & 0.79 \\
\hline 4 & 5.916 & -0.877 & Akotoana tributary & 0.36 \\
\hline 5 & 5.910 & -0.879 & Akotoana tributary & 0.12 \\
\hline 6 & 5.915 & -0.871 & Danyame & 0.26 \\
\hline 7 & 5.974 & -0.875 & Asokore tributary & 0.26 \\
\hline 8 & 5.978 & -0.880 & Asokore & 0.09 \\
\hline 9 & 5.926 & -0.846 & Tropea & 0.04 \\
\hline 10 & 5.956 & -0.845 & Atiankama & 0.31 \\
\hline 11 & 5.879 & -0.880 & Bimpon & 0.05 \\
\hline 12 & 5.941 & -0.897 & Ayena & 0.15 \\
\hline 13 & 5.912 & -0.777 & Supong tributary & 0.1 \\
\hline 14 & 5.958 & -0.783 & Santra Mo tributary & 0.07 \\
\hline 15 & 5.967 & -0.776 & Santra Mo & 0.02 \\
\hline 16 & 5.916 & -0.884 & Adim tributary & 0.22 \\
\hline 17 & 5.883 & -0.879 & Bimpon & 0.12 \\
\hline 18 & 5.940 & -0.765 & Supong & $0 *$ \\
\hline \multicolumn{4}{|c|}{ Average grade values for high terrace deposits } & 0.30 \\
\hline \multicolumn{5}{|c|}{ Low Terrace } \\
\hline 1 & 5.908 & -0.884 & Akotoana tributary & 0.11 \\
\hline 2 & 5.939 & -0.826 & Santra Mo tributary & 0.18 \\
\hline 3 & 5.932 & -0.810 & Ohiawa & 0.03 \\
\hline 4 & 5.909 & -0.785 & Esuboni & 0.02 \\
\hline 5 & 5.951 & -0.789 & Santra Mo tributary & 0.39 \\
\hline 6 & 5.946 & -0.789 & Santra Mo & 0.14 \\
\hline 7 & 5.950 & -0.807 & Santra Mo & 0.04 \\
\hline 8 & 5.950 & -0.770 & Asukoromoa & $0 *$ \\
\hline 9 & 5.921 & -0.786 & Supong & 0.03 \\
\hline 10 & 5.934 & -1.051 & Asika & 2.00 \\
\hline 11 & 5.971 & -1.175 & Birim & 1.40 \\
\hline \multicolumn{4}{|c|}{ Average grade values for low terrace deposits } & 0.43 \\
\hline \multicolumn{5}{|c|}{ Upland } \\
\hline 1 & 5.924 & -0.877 & Akotoana tributary & 0.25 \\
\hline 2 & 5.950 & -0.852 & Esuabeba Creek & 0.23 \\
\hline 3 & 5.985 & -0.780 & Esuboni & $0 *$ \\
\hline \multicolumn{4}{|c|}{ Average grade values for upland deposits } & 0.16 \\
\hline
\end{tabular}


Table 4. Average grade of Bonsa River diamond deposits by geomorphic type.

$\left[\mathrm{kt} / \mathrm{m}^{3}\right.$, carat per cubic meter; $<$, less than]

\begin{tabular}{|c|c|c|c|c|c|}
\hline Number & Latitude & Longitude & Stream & $\begin{array}{c}\text { Surficial } \\
\text { geomorphology }\end{array}$ & $\begin{array}{l}\text { Grade } \\
\left(\mathbf{k t} / \mathrm{m}^{3}\right)\end{array}$ \\
\hline 1 & 5.224 & -2.030 & Bediebewe & Alluvial Flat & $<0.50$ \\
\hline 2 & 5.169 & -2.106 & Tabu Su & High Terrace & 1.09 \\
\hline 3 & 5.238 & -2.013 & Awhitiaso and Cherifung confluence & High Terrace & 0.55 \\
\hline 4 & 5.180 & -2.087 & Enikawkaw & Low Terrace & 0.65 \\
\hline
\end{tabular}

\section{Methodology to Estimate the Diamond Production Capacity of Ghana}

Diamond production capacity is defined as the current volume of diamonds (calculated as total number of carats) which can be produced utilizing current human and physical resources. The estimate of diamond production capacity does not reflect the possibility of future introduction of new financial capital investment, improved exploration or mining techniques, nor does it model increases of human resources (labor capital) in the mining sector. Rather, it is a measure of the current state of the diamond-mining sector based on recent field data collected and on previous research studies of diamond mining, gravel grades, and records of mining companies currently involved in diamond mining, as well as estimates of the total number of alluvial diamond diggers and small mining cooperatives.

Observations made in the field during the two field excursions, and previous reports revealed that diamond mining rarely occurs in the Bonsa area or is only occurring as a secondary result of gold dredging operations. Therefore, the variables used to calculate the production capacity are based on data collected within the Birim study area. The following formula is used to calculate production capacity. It can be stated mathematically as:

$$
P_{i}=(V m / d g) d A_{i},
$$

where

$$
\begin{aligned}
& P_{i} \quad \text { is the total current production capacity, } \\
& \mathrm{Vm} / \mathrm{d}^{i} \quad \text { is the volume of material worked for each } \\
& \text { digger per day, } \\
& g \text { is the average gravel grade, } \\
& d \quad \text { is the total number of days that a digger works } \\
& \text { per year, and } \\
& A_{i} \quad \text { is the total number of diggers estimated to be } \\
& \text { actively mining diamonds. }
\end{aligned}
$$

Ghanaian artisanal miners utilize a high degree of mechanization. Many of the pits observed were stripped of overburden by mechanized excavator equipment. This degree of mechanization allows diggers to be more productive in extracting and washing gravels. However, many smaller operations still do not utilize the mechanization and are entirely hand dug. Human mining activity $(\mathrm{Vm} / \mathrm{d})$ is calculated to be $0.75 \mathrm{~m}^{3}$ per digger per day and takes into account the high degree of mechanization and also incorporates the average amount of overburden (stripping ratio), which ranges from 0 to 10:1 for the deposits but is averaged to be $3: 1$ for the Birim.

The grade $(g)$ parameter used for the evaluation is the weighted average of diamond grades for the Birim River deposits, which is calculated to be $0.68 \mathrm{kt} / \mathrm{m}^{3}$.

Mining activity in the Birim occurs mainly during the two dry seasons, from July to August and then again from December to April. There are considerable variations in precipitation, and the miners interviewed for this study stated that they were active from between 3 to 7 months of the year depending on local conditions, proximity to the river, and depth to the water table. Most mining sites reported that the mines were active 6 days a week during the mining seasons. For this study, an average of 150 days per year is used for the value of $d$.

The total number of diggers estimated during reconnaissance fieldwork $\left(A_{i}\right)$, including galamsey and registered diamond diggers, is approximately 10,000 . The $\mathrm{MC}$ had registered 6,420 diamond workers and tributers by March 2009. Approximately 34 percent of observed diamond diggers were not registered, especially in the middle and lower Birim areas. An estimated 2,000 to 3,000 currently unregistered diamond miners may still be unaccounted for. In addition, registered small-scale miners also account for an additional 600-700 diggers. While no reported information is available for the number of diamond diggers in the Bonsa, the numbers are estimated to be less than 1,000 . 


\section{Results of the Modified Volume and Grade Approach}

Table 5 shows the calculated diamond reserves in the Birim River study area. The table shows the surficial geomorphological deposit type, the average gravel thickness, the calculated volume of gravel, the average gravel grade, and the total calculated reserves. The majority of reserves (77 percent) are calculated to have been within the alluvial flat deposits because volume of gravel is the greatest and the average gravel grade is the highest. The method calculates that $183,599,267$ carats are calculated to have been present in the Birim diamond field. However, on the basis of previous production of diamonds in the Birim field, 94,500,000 carats are calculated to have already been mined.

Table 6 shows the calculated diamond reserves in the Bonsa River study area. The table shows the surficial geomorphological deposit type, the average gravel thickness, the calculated volume of gravel, the average gravel grade, and the total calculated reserves. The deposits of the Bonsa field cover a much smaller area, and the average grades are also significantly lower than those of the Birim field. As a result, the Bonsa field is calculated to have originally hosted just over 13,000,000 carats. Previous production in the Bonsa diamond field is calculated to have been 10,500,000 carats. The estimated reserves remaining in the Bonsa are calculated to be 2.6 million carats.

Table 5. Calculated diamond reserves in the Birim River diamond field.

[ $\mathrm{m}^{2}$, square meter; $\mathrm{m}$, meter; $\mathrm{m}^{3}$, cubic meter; $\mathrm{kt} / \mathrm{m}^{3}$, carat per cubic meter; kt, carat]

\begin{tabular}{|c|c|c|c|c|c|c|}
\hline $\begin{array}{l}\text { Geomorphic } \\
\text { deposit type }\end{array}$ & $\begin{array}{c}\text { Area } \\
\left(\mathrm{m}^{2}\right)\end{array}$ & $\begin{array}{c}\text { Average gravel } \\
\text { thickness } \\
(\mathrm{m})\end{array}$ & $\begin{array}{l}\text { Volume } \\
\left(\mathrm{m}^{3}\right)\end{array}$ & $\begin{array}{c}\text { Average } \\
\text { gravel grade } \\
\left(\mathrm{kt} / \mathrm{m}^{3}\right) \\
\end{array}$ & $\begin{array}{l}\text { Calculated } \\
\text { reserves } \\
\text { (kt) }\end{array}$ & $\begin{array}{c}\text { Percent of } \\
\text { calculated } \\
\text { reserves (kt) }\end{array}$ \\
\hline Alluvial Flat & $181,703,632.81$ & 1 & $181,703,632.81$ & 0.781 & $141,983,218.68$ & 0.77 \\
\hline Low Terrace & $112,862,825.65$ & 0.5 & $56,431,412.82$ & 0.436 & $24,604,095.99$ & 0.13 \\
\hline High Terrace & $221,722,596.50$ & 0.2 & $44,344,519.30$ & 0.299 & $13,259,011.27$ & 0.07 \\
\hline Upland & $234,558,834.95$ & 0.1 & $23,455,883.50$ & 0.16 & $3,752,941.36$ & 0.02 \\
\hline \multicolumn{4}{|c|}{ Calculated volume of diamonds previously mined from Birim diamond field } & \multicolumn{3}{|c|}{$94,500,000.00$} \\
\hline \multicolumn{4}{|c|}{ Total calculated reserve remaining } & \multicolumn{3}{|c|}{$89,099,267.30$} \\
\hline
\end{tabular}

Table 6. Calculated diamond reserves in the Bonsa River diamond field.

$\left[\mathrm{m}^{2}\right.$, square meter; $\mathrm{m}$, meter; $\mathrm{m}^{3}$, cubic meter; $\mathrm{kt} / \mathrm{m}^{3}$, carat per cubic meter; $\mathrm{kt}$, carat]

\begin{tabular}{|c|c|c|c|c|c|c|}
\hline $\begin{array}{l}\text { Geomorphic } \\
\text { deposit type }\end{array}$ & $\begin{array}{c}\text { Area } \\
\left(\mathrm{m}^{2}\right)\end{array}$ & $\begin{array}{c}\text { Average gravel } \\
\text { thickness } \\
\text { (m) }\end{array}$ & $\begin{array}{c}\text { Volume } \\
\qquad\left(\mathrm{m}^{3}\right)\end{array}$ & $\begin{array}{c}\text { Average } \\
\text { gravel grade } \\
\left(\mathrm{kt} / \mathrm{m}^{3}\right)\end{array}$ & $\begin{array}{l}\text { Calculated } \\
\text { reserves } \\
\text { (kt) }\end{array}$ & $\begin{array}{c}\text { Percent of } \\
\text { calculated } \\
\text { reserves } \\
\text { (kt) }\end{array}$ \\
\hline Low Terrace & $29,409,932.29$ & 0.3 & $8,822,979.69$ & 0.25 & $2,205,744.92$ & 0.17 \\
\hline High Terrace & $41,224,644.79$ & 0.15 & $6,183,696.72$ & 0.125 & $772,962.09$ & 0.06 \\
\hline \multicolumn{5}{|l|}{ Total } & $13,124,329.50$ & \\
\hline \multicolumn{5}{|c|}{ Calculated volume of diamonds previously mined from Bonsa diamond field } & $10,500,000.00$ & \\
\hline \multicolumn{5}{|c|}{ Total Calculated Reserve Remaining } & $2,624,329.50$ & \\
\hline
\end{tabular}




\section{Results of the Diamond Production Capacity}

The diamond production capacity model was used to calculate the estimated production capacity of the Ghanaian diamond industry:

$$
P_{i}=(V m / d g) d A_{i}
$$

where

$$
\begin{aligned}
& P_{i} \quad \text { is the total current production capacity, } \\
& \mathrm{Vm} / \mathrm{d} \quad \text { is the volume of material worked for each } \\
& \text { digger per day }\left(0.75 \mathrm{~m}^{3}\right) \text {, } \\
& g \quad \text { is the average gravel grade }\left(0.68 \mathrm{kt} / \mathrm{m}^{3}\right) \text {, } \\
& d \text { is the average number of days that the } \\
& \text { diamond diggers are active (150), and } \\
& A_{i} \quad \text { is the estimated number of active diggers in } \\
& \text { Ghana (10,000). }
\end{aligned}
$$

Given the parameters above, the calculation of production capacity is:

$$
765,000=(0.75 \times 0.68) \times 150 \times 10,000
$$

\section{Conclusion}

The goal of this study was to estimate the alluvial diamond resource endowment and the current production capacity of the alluvial diamond-mining sector of Ghana. A modified volume and grade methodology was used to estimate the remaining diamond reserves within the Birim and Bonsa diamond fields. The production capacity of the sector was estimated using a formulaic expression of the number of workers reported in the sector, their productivity, and the average grade of deposits mined. This study estimates that there are approximately 91,600,000 carats of alluvial diamonds remaining in both the Birim and Bonsa diamond fields. This figure is just less than the reported 105 million carats exported from Ghana since the 1920s.

An estimated 89,000,000 carats remain in the diamondiferous subbasins of the Birim River and its tributaries. Kesse (1985) noted that studies of the lower, middle, and upper Birim had calculated 50,000,000 carats contained within the GCD concession boundaries. These two estimates seem consistent when viewing the diamondiferous nature of the entire Birim field. It is important to note that many of the remaining deposits in the Birim may not be considered commercially viable due to the patchy and low-grade nature of the deposits. In addition, it is likely that in the future, miners in the Birim will need to remove more overburden, as the shallow and richer deposits have largely been mined out, thus increasing the stripping ratio and decreasing the productivity.

Approximately 2,600,000 carats are estimated to remain in the Bonsa. The deposits in the Bonsa seem to represent a very small overall contribution to the Ghanaian diamond reserves. These deposits were only being mined as a byproduct of gold dredging and artisanal mining. These deposits do not seem to be a commercially viable source for diamond mining in the future.

The mining situation in the Birim and Bonsa may be more ideally suited toward artisans who have lower overhead and operating costs as compared to large-scale operations run by companies such as GCD. The wide geographic distribution of the deposits in the Birim also favors exploitation by artisans who are highly mobile and treat and wash the gravels locally, as opposed to transporting untreated gravels by road to large mechanical washing and sorting plants.

Production capacity is calculated to be 765,000 carats per year, based on the formula and available data on the number of workers and worker productivity. This number is generally higher than the 600,000 carat average produced in Ghana from the 1980s and 1990s, yet it is slightly lower than the nearly 900,000 carat-per-year production average for the past 10 years. The difference in these numbers reflects the lack of sufficient data on diamond resource grades, worker productivity, and the number and locations of sites currently being worked. Annual production is highly dependent on the international diamond market and prices, the numbers of seasonal workers actively mining in the sector, and environmental conditions, which influence seasonal farming.

It remains challenging to acquire data at the level of detail required to accurately estimate the parameters for alluvial diamond resources. In this study, calculations were made based on modeling of the parameters of alluvial deposits, grades of deposits, and human resources engaged in the artisanal mining sector. These calculations are based on substantial historical research and on field observations, interviews, and geomorphologic mapping of the deposits. However, reliable information on the grades of the remaining diamond deposits of Ghana is scarce, and field studies to acquire this type of data are costly and require extensive periods of time in the field. Additional field mapping of the Birim and Bonsa could improve data on geomorphologic deposits, grade data, and the number and location of active mining sites.

A significant improvement of this study over previous methods of calculating diamond reserves is the adoption and use of terrain modeling and geomorphic mapping of the alluvial flats, low terraces, high terraces, and upland deposit types. This spatially based methodology bears closer resemblance to field conditions than previous methods and may be a more realistic model of the extent of the deposit than previous methods. More accurate grade and thickness measures would significantly improve the model and resulting calculations. 


\section{References Cited}

Amankwah, R.K., and Anim-Sackey, C., 2003, Strategies for sustainable development of the small-scale gold and diamond mining industry of Ghana: Resources Policy, v. 29, p. 131-138 (also available at $h t t p: / / d x . d o i . o r g / 10.1016 / j$. resourpol.2004.07.002).

Appiah, H., Norman, D.I., and Kuma, J.S., 1996, The diamond deposits of Ghana: Africa Geoscience Review, v. 3, no. 2, p. 261-272.

Archives Rehabilitation Unit, 2003a, The Bonsa diamondfield ( $2 \mathrm{~d}$ ed.), in Kitson, A.E., Junner, N.R., Hirst, T., McGregor, D.P., and Service, H., Reports, letters and notes, Archive Report No. 15: Ghana Geological Survey Department, p. $1-69$.

Archives Rehabilitation Unit, 2003b, The geology of the 1/4 (2d ed.), in Van Es, E., Field sheet nos. 47, 48, 49 and 50, Dunkwa, Archives Report No. 41: Ghana Geological Survey Department, v. 1, p. 1-138.

Archives Rehabilitation Unit, 2003c, The geology of the 1/4 (2d ed.), in Van Es, E., Field sheet nos. 47, 48, 49 and 50, Dunkwa, Archives Report No. 41: Ghana Geological Survey Department, v. 2, p. 1-178.

Archives Rehabilitation Unit, 2003d, The geology of the 1/4 (2d ed.), in Gammon, J.F., Field sheet no. 57, Nsaba NW, and no. 93, Kibi SW, Archives Report No. 67: Ghana Geological Survey Department, p. 1-101.

Barthélémy, F., and others, 2006, Republic of the Congo, diamond potential, production capacity, and the Kimberley Process-Final report: Bureau de Recherches Géologiques et Minières, RC-54589-EN, 99 p.

Canales, Dylan G., 2005, The Akwatia diamond field, Ghana, West Africa-Source rocks: Socorro, New Mexico Institute of Mining and Technology, M.Sc. dissertation, 143 p.

Chirico, P.G., Barthélémy, Francis, and Koné, Fatiaga, 2010a, Alluvial diamond resource potential and production capacity assessment of Mali: U.S. Geological Survey Scientific Investigations Report 2010-5044, 23 p.

Chirico, P.G., Barthélémy, Francis, and Ngbokoto, F.A., $2010 \mathrm{~b}$, Alluvial diamond resource potential and production capacity assessment of the Central African Republic: U.S. Geological Survey Scientific Investigations Report 2010-5043, 22 p.

Coakley, G.J., 1995, The mineral industry of Ghana: U.S. Geological Survey Minerals Yearbook, v. 3, 8 p.
Ghana Consolidated Diamonds Ltd., 1982, A study of the conventional mining of the Birim Deposits as an extension to the existing GCD Akwatia operation: Accra, Ghana, Ghana Consolidated Diamonds Ltd., p. 1-16.

Greenhalgh, P.A.L., 1985, West African diamonds, 19191983-An economic history: Manchester, Manchester University Press, 306 p.

Hall, A.M., Thomas, M.F., and Thorp, M.B., 1985, Late Quaternary alluvial placer development in the humid tropicsThe case of the Birim diamond placer, Ghana: Journal of the Geological Society of London, v. 142, no. 5, p. 777-787.

Hilson, Gavin, 2001, A contextual review of the Ghanaian small-scale mining industry: London, Mining Minerals and Sustainable Development Project, World Business Council for Sustainable Development, no. 76, 29 p.

Junner, N.R., 1931, Geological notes on the Birim diamondfield: Geological Survey Department of the Gold Coast, Annual Report, p. 2-4.

Junner, N.R., 1936, The Bonsa diamond field, Gold Coast Colony: Bulletin of the Imperial Institute, v. 34, no. 3, p. 373-374.

Junner, N.R., 1943, Diamonds of the Gold Coast [abs.]: South African Mining and Engineering Journal, v. 54, pt. 1, no. 2636 , p. $483-487$.

Kesse, G.O., 1985, The mineral and rock resources of Ghana: Boston, Balkema Publishers, $610 \mathrm{p}$.

Kimberley Process Certification Scheme (KPCS), 2007, Report of the Review Mission to the Republic of Ghana, March 26-30, 2007, 41 p.

Kitson, A.E., 1919, Report on the discovery of diamonds at Abomosu, northwest of Kibbi, Eastern Province, Gold Coast: Government Session Paper IX of 1918-1919, Geological Survey of Ghana Library.

Leube, Alfred, Hirdes, Wolfgang, Mauer, Rudolf, and Kesse, G.O., 1990, The Early Proterozoic Birimian supergroup of Ghana and some aspects of its associated gold mineralization: Precambrian Research, v. 46, p. 139-165.

McCready, Peter, ed., 2006, Ghana-A mining journal supplement: London, Mining Communications Ltd., p. 2-7.

McKitrick, S.A., Norman, D.I., and Appiah, H., 1993, Proterozoic Ghanaian metakimberlites [abs.]: American Geophysical Union Fall Meeting, December 6-10, 1993, San Francisco.

Olsson, Ola, 2006, Diamonds are a rebel's best friend: The World Economy, Blackwell Publishing, v. 29, no. 8, p. 1133-1150. 
Schlüter, Thomas, 2006, Geological atlas of Africa, with notes on stratigraphy, tectonics, economic geology, geohazards and geosites of each country: Berlin: Springer, $272 \mathrm{p}$.

Strahler, A.N., 1964, Quantitative geomorphology of drainage basins and channel networks, in Chow, V.T., ed., Handbook of applied hydrology: McGraw-Hill, p. 4-40.

Teeuw, R.M., Thomas, M.F., and Thorp, M.B., 1991, Geomorphology applied to exploration for tropical placer deposits, in Conference on Alluvial Mining, London, U.K., 1991, Proceedings: London, Institution of Mining and Metallurgy, p. $458-480$.
Tsikata, F.S., 1997, The vicissitudes of mineral policy in Ghana: Resources Policy, v. 23, no. 1, p. 9-14.

University of Ghana, 1989, The diamond fields in Ghana (updated), in Prospectus on gold and diamonds in Ghana: A report prepared by the Geology Department of the University of Ghana, Legon, for the Minerals Commission and the United Nations Department of Technical Cooperation for Development, 33 p., 4 pls.

Wright, J.B., Hastings, D.A., Jones, W.B., and Williams, H.R., 1985, Geology and mineral resources of West Africa: London, George Allen and UnWin [Publishers], 187 p.

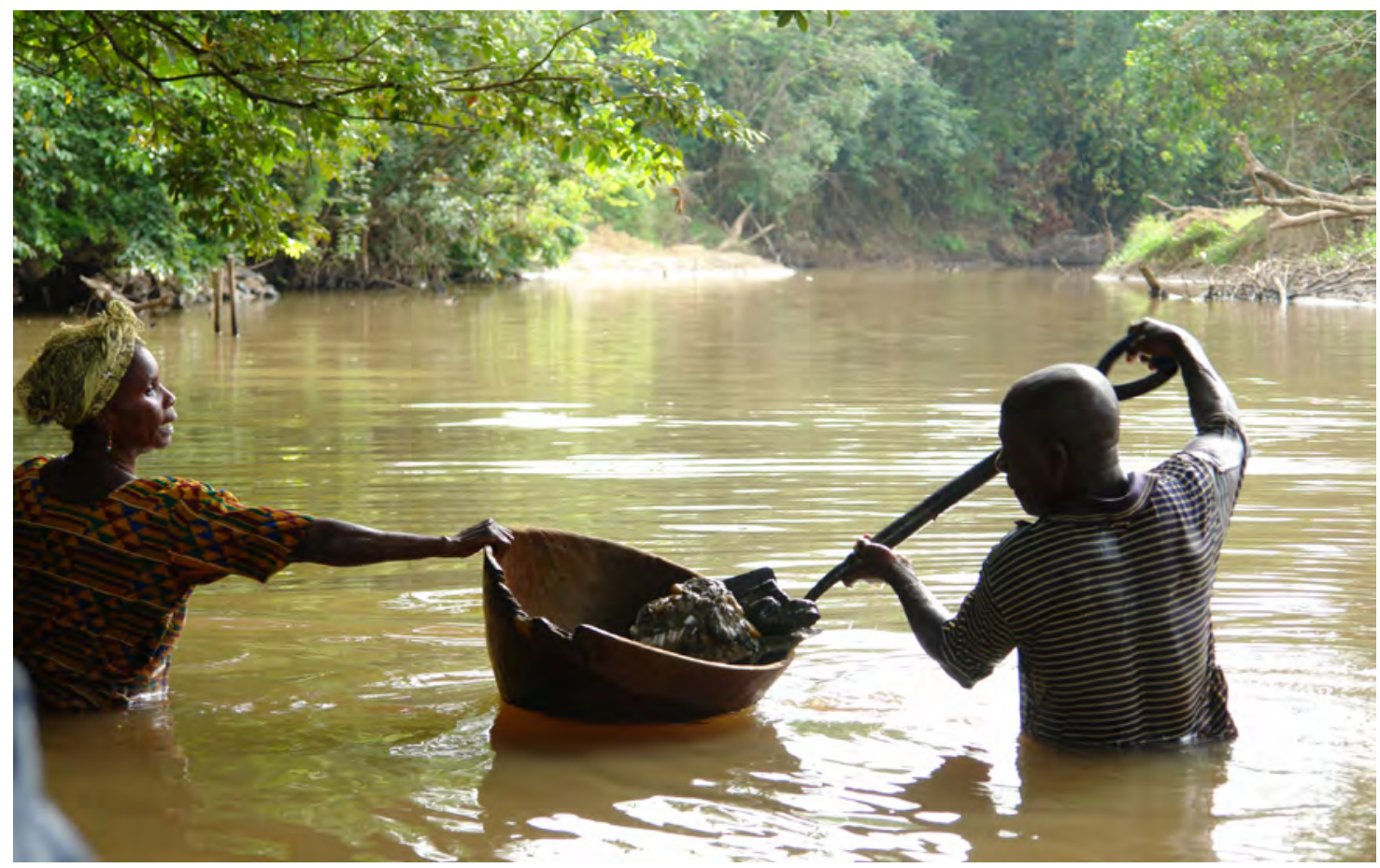

Artisanal diamond miners collecting gravels from the bed of the Bonsa River, March 2009 
